OPEN ACCESS

Edited by:

Ashutosh Mittal,

National Renewable Energy

Laboratory (DOE), United States

Reviewed by:

Yunqiao $\mathrm{Pu}$

Oak Ridge National Laboratory (DOE),

United States

Muzaffer A. Karaaslan,

The University of British Columbia,

Canada

*Correspondence:

Manjusri Misra

mmisra@uoguelph.ca

†Mohamed A. Abdelwahab, On leave from the Department of Chemistry, Faculty of Science, Tanta

University, Tanta, Egypt

Specialty section:

This article was submitted to

Bioenergy and Biofuels,

a section of the journal

Frontiers in Energy Research

Received: 16 April 2020

Accepted: 04 August 2020

Published: 09 September 2020

Citation:

Poursorkhabi V, Abdelwahab MA, Misra $M$, Khalil $H$, Gharabaghi $B$ and

Mohanty AK (2020) Processing, Carbonization, and Characterization of Lignin Based Electrospun Carbon

Fibers: A Review.

Front. Energy Res. 8:208.

doi: 10.3389/fenrg.2020.00208

\section{Processing, Carbonization, and Characterization of Lignin Based Electrospun Carbon Fibers: A Review}

\author{
Vida Poursorkhabi',2, Mohamed A. Abdelwahab ${ }^{1,2 \dagger}$, Manjusri Misra ${ }^{1,2 *}$, Hamdy Khalii ${ }^{3}$, \\ Bahram Gharabaghi' ${ }^{1}$ and Amar K. Mohanty ${ }^{1,2}$ \\ 1 School of Engineering, University of Guelph, Guelph, ON, Canada, ${ }^{2}$ Bioproducts Discovery and Development Center, \\ Department of Plant Agriculture, University of Guelph, Guelph, ON, Canada, ${ }^{3}$ The Woodbridge Group, Woodbridge, ON, \\ Canada
}

Greenhouse gas emissions and environmental impacts of petroleum-based fuels and materials have necessitated the development of renewable resource-based alternatives. In the process to extract cellulose for converting it to bioethanol (bio-based gasoline) large quantities of lignin are produced as the main byproduct-making it useful for further processing application for sustainable materials. Lignin is the second abundant source of renewable carbon with an aromatic structure which makes it a potential candidate for carbon fiber production. Since lignin can be dissolved in a variety of organic and non-organic solvents, electrospinning has been used to produce precursor fibers for carbon nanofiber production. These carbon nanofibers have been tested as a potentially sustainable alternative for the current non-renewable electrodes in energy storage and conversion devices such as supercapacitors. Using lignin by-products from the fuel energy sector in making devices for electrical energy sector provides a great opportunity for promoting a circular economy from sustainable materials while also contributing to researching alternative sustainable materials in light of a global pandemic. This review presents a summary of the processing conditions for electrospinning different varieties of lignin, characterization of the electrospun fibers and the carbonization conditions for converting fibers. Different techniques that of the structural properties of the precursor fibers, characteristics of carbon nanofibers and their performance in energy storage devices are discussed. Compared to the other published reviews in this field, this review aims to present the current knowledge on material-processing-lignin-carbon fibers properties relationship.

Keywords: electrospinning, lignin, carbon fiber, fiber properties, heat treatment 


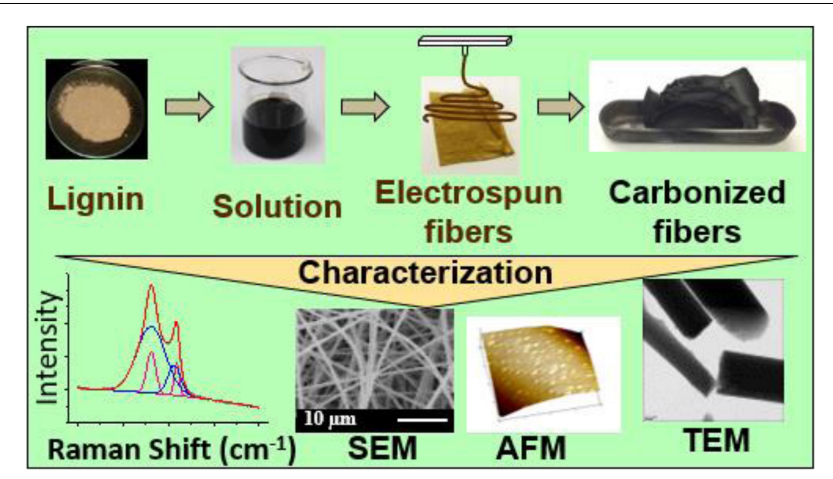

GRAPHICAL ABSTRACT | Electrospun lignin fibers are sustainable and renewable resource-based alternatives to current petroleum-based precursors for carbonized fibers. Production, carbonization, and characterization of lignin fibers are essential for their effective utilization.

\section{INTRODUCTION}

Environmental institutes set new targets for vehicle engine emissions. Two of the approaches to reach the targeted values are reducing the vehicle weight by using high-performance, lightweight materials and also substituting a fraction of gasoline with bioethanol or other alternative sources of energy (Mainka et al., 2015b; Mohanty et al., 2018).

Addition of bioethanol to gasoline improves the engine performance and reduces emissions (Zhao and Wang, 2020). The economic viability of bioethanol production from sustainable lignocellulosic resources highly depends on the utilization of the process' byproducts for highvalue applications. The major byproduct of bioethanol production from lignocellulosic materials is lignin which is one of the most highly available resources of renewable carbon (Solomon et al., 2007; Dessureault, 2014). Compared to cellulose and other sources of renewable carbon, lignin is a good candidate for the production of carbon fibers owing to the aromatic structure, presence of phenolic and aliphatic hydroxyl groups, high carbon content, thermal stability and availability as a waste product from biomass (Fang et al., 2017a).

Advances in the production of efficient energy storage and conversion devices, such as electrodes have led to the emerging utilization of carbon nanofibers. The average annual growth of global carbon fiber is around 58,000 tons in 2015 (Figure 1; Fang et al., 2017a). It is estimated that carbon fiber polymer composites will reach 197,000 tons in 2023 (Sauer, 2019). For an economic comparison, current petroleum-based carbon fibers have a high manufacturing cost of $\sim$ USD $\$ 10.20$ per lb (according to the annual production of 1,500 tons/year (Mainka et al., 2015b; Yoo et al., 2017) whereas utilization of lignin costs $\sim$ USD \$ 0.5 per $\mathrm{lb}$, including spinning for the production of carbon fibers which can reduce the cost to $\sim$ USD $\$ 2.86$ per lb (Fang et al., 2017a). The lower cost of lignin-based carbon fibers provides an opportunity for a wider range of industries

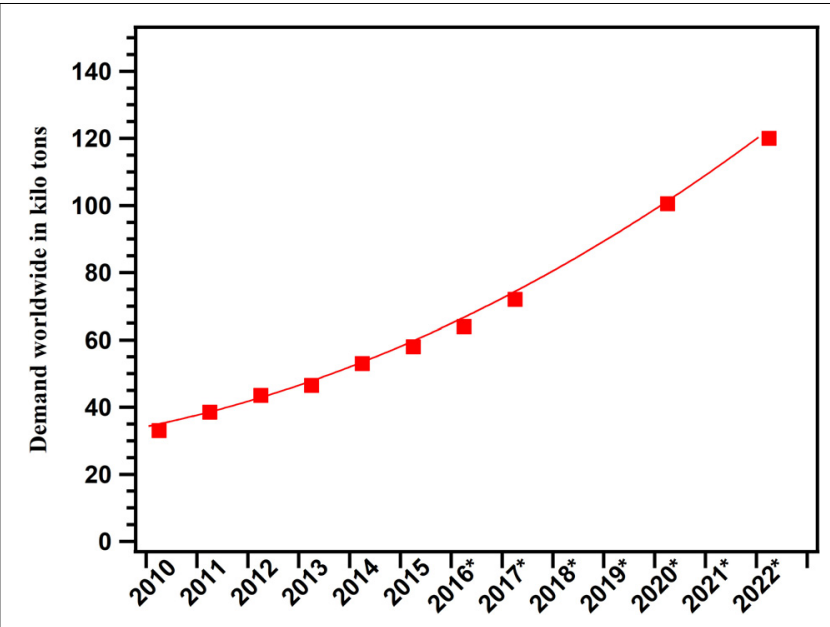

FIGURE 1 | Global demand for carbon fibers in kilo tons from 2010 to 2022. Data adapted from Fang et al. (2017a) with permission from The Royal Society of Chemistry (Order license ID: 1029647-1) ('Estimates).

to benefit from the advantages of these renewable sustainable fibers. Carbon nanofibers have been used to replace the inorganic components and improve the efficiency and performance of renewable energy storage/conversion devices (Zhang et al., 2016). Several review papers have been published to summarize the research data on electrospinning various types of lignin, their carbonization and properties of the devices fabricated using the carbon nanofibers (Li et al., 2016; Fang et al., 2017a; GarcíaMateos et al., 2019; Kumar et al., 2019; Wei J. et al., 2019). There are a limited number of comprehensive studies that determine the relationship between the type and properties of lignin - electrospinning process parameters - electrospun fiber properties - carbonization parameters - carbon nanofiber properties, and final performance of the energy storage and conversion devices. The goal of this review is to present a summary of the research reports which describe the materials processing - performance relationship.

\section{Lignin Structure, Sources, and Applications}

Lignin is a heterogeneous, polyaromatic biopolymer comprising $\sim 30 \%$ of organic carbon on the earth (Suhas et al., 2007; Achyuthan et al., 2010; Saito et al., 2012). The lignin content of different biomass varies by type, and it is present in the cell walls of lignocellulosic material (Suhas et al., 2007; Kumar et al., 2009; Laurichesse and Avérous, 2014; Zeng et al., 2014). The monomers and the proposed structure of lignin are represented in Figure 2. The lignin monomer structure is attached with different types of bonds and about $48-60 \%$ of the interunit linkages are $\beta-O-4$ linkage (aryl-glycerol- $\beta$-O-4 aryl ether) (Braun et al., 2005).

Softwoods primarily compose of guaiacyl $(G)$ units, with traces of syringyl $(\mathrm{S})$ and p-hydroxyphenyl $(\mathrm{H})$ units present as well. Softwood lignins only have coniferyl alcohol units. Hardwood lignins have both G and S units. Grass or yearly 


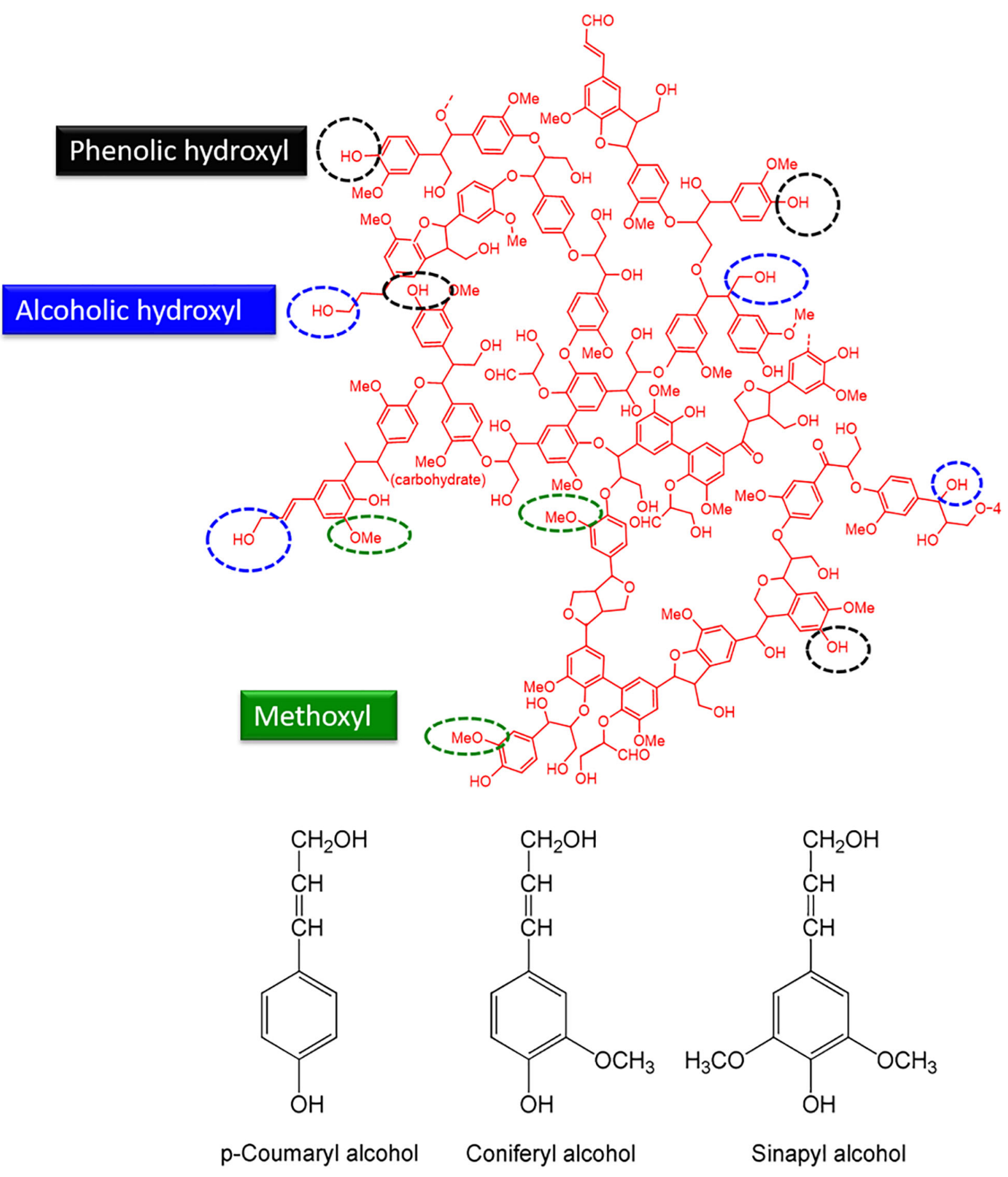

FIGURE 2 | Proposed structure of lignin with the main functional groups and the monomers of lignin (Fang et al., 2017a) with permission from The Royal Society of Chemistry (Order license ID: 1029450-1).

plant lignins have all three units ( $G, S$, and $H$ units) which likely increase economic efficiency in mass production of lignin (Suhas et al., 2007).

Cellulosic ethanol and paper/pulp production are two leading industries that produce lignin as their coproducts $\mathrm{Hu}$ and Hsieh, 2013; Poursorkhabi et al., 2013; Chen et al., 2014;
Abdelwahab et al., 2015, 2019; Poursorkhabi et al., 2016; Adams et al., 2018). Alkaline pulping (soda and kraft) are the most common methods to extract lignin from cellulose in paper/pulp manufacturing (Suhas et al., 2007). Paper processes often have high salts and ash content in lignin as well as sulfur-based groups contamination (Lora and Glasser, 2002; Lallave et al., 2007; 
A
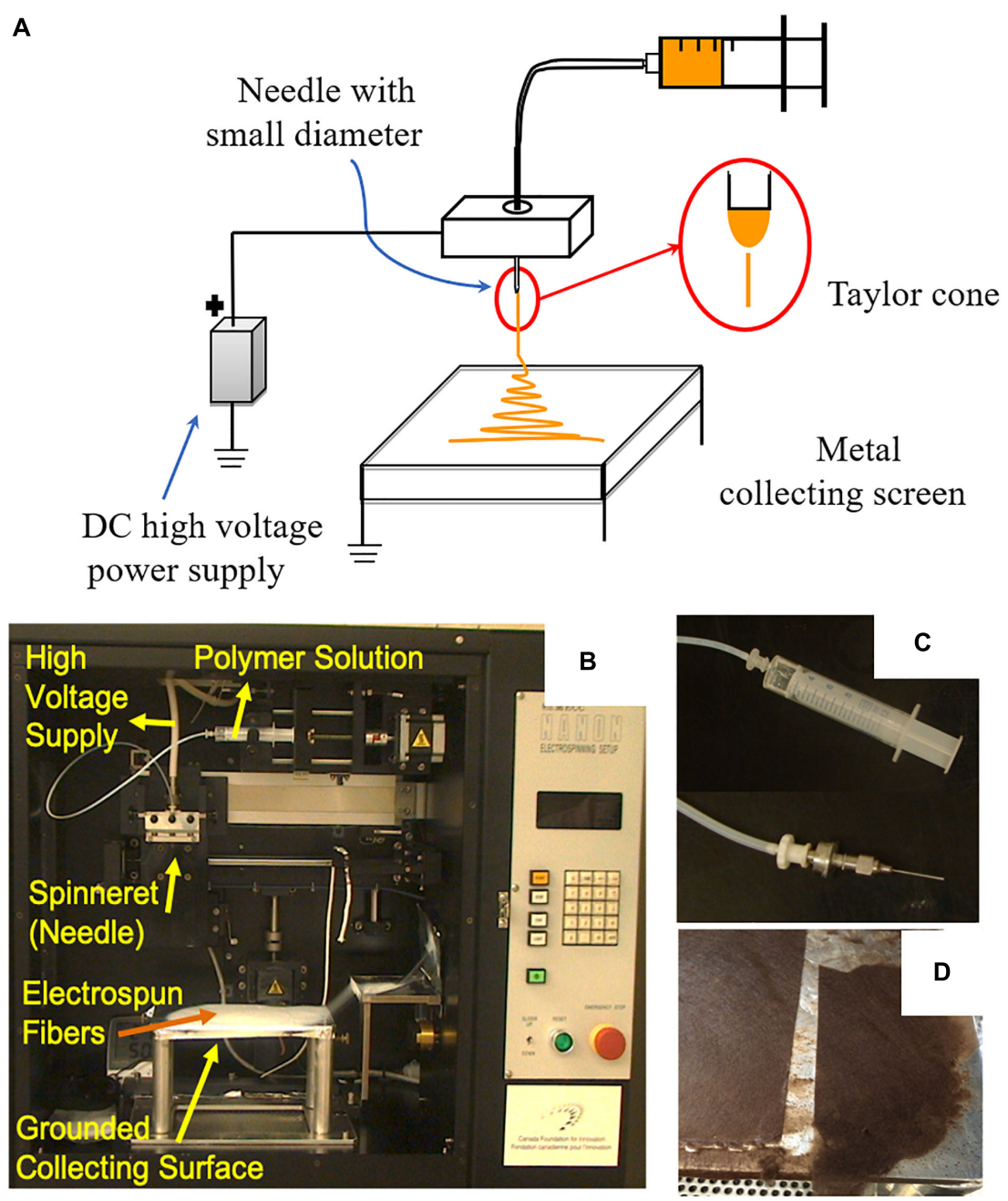

FIGURE 3 | (A) Schematic diagram of electrospinning set up (vertical set-up) reproduced from Poursorkhabi (2016); (B) Front view of a commercial electrospinning machine showing the main parts of the process [NANON-01, MECC Co. (Japan)]; (C) Needle and syringe connections and (D) Sample of collected lignin fibers on a flat collector (B-D are original pictures from the Bioproducts Discovery and Development Centre).

Hatakeyama and Hatakeyama, 2010). Biomass conversion technologies use sulfur-free processes. Lignin obtained from these processes has a wide molecular weight distribution and displays different characteristics compared to sulfite and kraft lignin (Lora and Glasser, 2002). The properties of lignins, the extent of hydrolytic degradation, chemical functionalities, and molecular weight depends on the processing conditions and the nature of biomass (Braun et al., 2005; Hu and Hsieh, 2013). Both softwood (Aslanzadeh et al., 2017; Cho et al., 2017, 2018; Roman et al., 2019) and hardwood lignin (Teng et al., 2013; Schreiber et al., 2015; Culebras et al., 2019; Schlee et al., 2019b; Yun et al., 2019) have been used for producing carbon nanofibers. However, most of the literature has studied hardwood lignin. More research is needed to be done to compare the processing and properties of carbon nanofibers obtained from softwood and hardwood lignin under similar processing conditions. Since lignin is produced as a by-product of another industry, i.e., paper and bioethanol, availability of any kind of it is dependent on the economy of these industries. Therefore, the best option is to optimize the production of carbon nanofibers based on the highest available types resulting from the most conventional paper or bioethanol processes.

\section{Electrospinning}

Electrospinning process is a convenient and low-cost method to produce continuous fibers (1D structure) at ambient temperatures with micro- to nanometer diameters (Bhardwaj and Kundu, 2010; Inagaki et al., 2012; Poursorkhabi et al., 2016). Nanoparticles (e.g., $\mathrm{CuO}, \mathrm{NiO}, \mathrm{ZnO}$, etc.) dispersed or embedded in the solution can be incorporated into the polymer to enhance the mechanical and physical characteristics of the matrix providing new advantages for carbon nanofibers in chemical sensing, energy, and catalysis applications (Huang et al., 2003; Tan et al., 2007; Kumar et al., 2012; Xu et al., 2013). In the electrospinning process (Figure 3), a polymer solution is placed into a reservoir (syringe), which is attached to a needle in the 
top position (vertical set-up) or on the side position (horizontal set-up) of a conductive surface (collector). The spinning begins by charging the needle and pumping the solution that produce drops at the tip of the needle. The Taylor cone (the droplet) gets charged and suctioned into the electrical field between needle and collector, which is grounded. A thin electrified solution jet is suctioned from the droplet when the electrostatic force on the droplet becomes more significant than the surface tension. The jet goes through rapid and unstable whipping motion between the tip and the collector in which the solvent evaporates leaving a fiber material on the collector (Reneker et al., 2000; Ramakrishna et al., 2005; Reneker and Yarin, 2008).

Parameters that affect the electrospinning process and quality of the fibers are material types, processing, environmental conditions, and design. Material properties determine their ability to create fibers. The most important properties in this group are solution viscosity or concentration and molecular weight of the polymer. Higher molecular weight polymers are more suitable for spinning (Deitzel et al., 2001; Li and Wang, 2013). Different processing parameters lead to different geometry, and fiber diameter properties (Thompson et al., 2007; Alghoraibi and Alomari, 2018; Prabu and Dhurai, 2020). The main processing parameters which can be modified include voltage and feeding rate (Teo et al., 2011; Kumar et al., 2012). Increased voltage and decreased feeding rates reduce the fiber diameter (Beachley and Wen, 2009; García-Mateos et al., 2019). Environmental conditions such as temperature and humidity can affect the morphology and the diameter of the fiber (Li and Wang, 2013).

Various designs of electrospinning set-up have been used to increase the throughput of the process or to create different fiber geometries. In needleless setup, the polymer solution is kept in a charged bath and collector is mostly in the shape of a drum rotating on top of the solution bath (Wei L. et al., 2019). During the process, jets of solution emerge from the solution bath and go towards the collector. Another method is co-axial electrospinning where a hollow or core-shell geometry is generated depending on the geometry of the needle (Teo et al., 2011; Persano et al., 2013; Han and Steckl, 2019).

\section{Electrospinning of Lignin}

Electrospinning solutions of lignin alone result in electrospraying of particles because lignin cannot create enough chain entanglements within the solution (Lai et al., 2014b). Multiple approaches used to electrospin lignin include; blending with a second polymer (binder polymer), co-electrospinning, and solvent fractionation to remove the low molecular weight fractions (Table $\mathbf{1}$ ).

Poly (ethylene oxide) (PEO) is particularly suited polymer to combine with lignin for electrospinning. PEO is miscible with lignin and is water-soluble. A solution of lignin with high molecular weight $\left(\mathrm{M}_{\mathrm{W}}\right)$ PEO in either alkaline water or organic solvents enhances the spinnability and solution elasticity (Kadla and Kubo, 2003; Kubo and Kadla, 2006; Dallmeyer et al., 2010; Schreiber et al., 2012; Poursorkhabi et al., 2015). A higher concentration of alkali hydroxides in the aqueous solutions of $\mathrm{PEO}$ and lignin causes further deterioration in fiber diameter due to improved charge density as well as charge dissipation (Hu and Hsieh, 2013).

Solutions of polyacrylonitrile (PAN) and lignin in DMF $(N, N-$ dimethyl formamide) have been electrospun to replace a part of PAN with lignin in the fibers (Seo et al., 2011; Choi et al., 2013). The conductivity and viscosity of PAN-lignin solutions decreased by increasing the lignin concentration (Seo et al., 2011). Thinner fibers were spun from solutions with lower viscosities (Choi et al., 2013). Core-shell fibers were formed by electrospinning cellulose nanofibers as core and PAN/lignin solution as a shell (Xu et al., 2013).

Electrospinning lignin blends with biobased polymers such as cellulose (Ahn et al., 2014), soy protein (Salas et al., 2014), cellulose acetate (Schreiber et al., 2015) and chitosan (Schreiber et al., 2014) have also been reported. Ahn et al. (2014) investigated the electrospinning of lignin and cellulose by direct blending and by partially delignification of hemp fibers to have natural blends of cellulose and different amount of lignin. Salas et al. (2014) investigated the electrospinning of kraft lignin and soy protein in the presence of coadjutant PEO and found an enhancement in the fiber diameter by an increasing amount of lignin and there is a H-bond interaction between lignin and soy protein. Schreiber et al. studied electrospinning of lignin with cellulose acetate (Schreiber et al., 2015) and with chitosan (Schreiber et al., 2014) to improve the carbonization process. They found a good interaction between lignin and cellulose acetate. Lignin/chitosan (in a ratio of 4:3) solution was found to be the best ratio to produce a good fiber due to the balanced charge ratio of lignin and chitosan functional groups.

Polymer blending of lignin with other polymers enhances the characteristics of lignin, however, it will increase the cost of the final product. Hence, retaining the proportion of the polymer binder as low as possible is preferred. Without the addition of an extra polymer (free binder), Lallave et al. (2007) produced coelectrospinning method for spinning lignin (organosolv lignin with low $\mathrm{M}_{\mathrm{w}}$ ). In the co-electrospinning process, a tri-axial configuration was used. In this configuration, ethanol, lignin solution, and glycerin solution were the outer layer, middle layer, and the inner layer, respectively. Hollow carbon fibers have been produced from co-electrospun fibers.

\section{Production of Carbon Fiber From Lignin-Based Fibers}

For producing carbon fibers, a thermostabilization process precedes carbonization. Thermostabilization involves slow air oxidation and cross-linking of the material to raise or remove its thermal transition points. This prohibits the melting of the fibers during carbonization (Braun et al., 2005; Ruiz-Rosas et al., 2010b). There is no melting point for lignin, however, glass transition temperature $\left(T_{g}\right)$ is an important parameter that impacts lignin's mobility and thermal flow. The $T_{g}$ of lignin and most of the carbon fiber precursors are lower than their thermal decomposition temperature. Therefore, the first processing step is to thermally stabilize the material and prevent fibers softening and fusion prior to the carbonization (RuizRosas et al., 2010b). The second thermal treatment process, 
TABLE 1 | Solution composition and spinning conditions for electrospinning of lignin.

\begin{tabular}{|c|c|c|c|c|c|c|c|c|c|}
\hline \multicolumn{3}{|c|}{ Material } & \multicolumn{2}{|c|}{ Solution composition } & \multicolumn{4}{|c|}{ Spinning conditions } & \multirow[t]{2}{*}{ References } \\
\hline Lignin type & $\begin{array}{l}\text { Binder } \\
\text { polymer }\end{array}$ & Solvent & $\begin{array}{l}\text { Lignin/Binder } \\
\text { polymer (wt/wt\%) }\end{array}$ & $\begin{array}{l}\text { Total polymer } \\
\text { conc. (wt/v\%) }\end{array}$ & $\begin{array}{l}\text { Voltage } \\
\text { (kV) }\end{array}$ & $\begin{array}{l}\text { Feed rate } \\
\text { (mL/min) }\end{array}$ & $\begin{array}{l}\text { Distance } \\
\text { (cm) }\end{array}$ & $\begin{array}{l}\text { Needle } \\
\text { gauge }\end{array}$ & \\
\hline $\begin{array}{l}\mathrm{SKL}^{1}, \mathrm{HKL}^{2} \text {, } \\
\text { Alcell lignin, } \\
\mathrm{SOL}^{3}, \text { Pyrolytic } \\
\text { lignin }\end{array}$ & $\mathrm{PEO}^{4}$ & $\mathrm{DMF}^{5}$ & $99 / 1-95 / 5$ & $20-50$ & $9-14$ & 0.03 & $14-20$ & 18 & Dallmeyer et al., 2010 \\
\hline SulKL ${ }^{6}$, LS $^{7}$ & $\mathrm{PEO}^{4}$ & Water & $99 / 1-95 / 5$ & $10-50$ & $9-14$ & 0.03 & $14-20$ & 18 & Dallmeyer et al., 2010 \\
\hline Alkali Lignin ${ }^{12}$ & PAN $^{8}$ & $\mathrm{DMF}^{5}$ & $\begin{array}{l}\text { 0/100, 50/50, } \\
60 / 40,70 / 30 \\
80 / 20\end{array}$ & - & 15 & 0.02 & 10 & 25.5 & Seo et al., 2011 \\
\hline $\begin{array}{l}\text { Fractionated } \\
\text { SKL }^{9}\end{array}$ & $\mathrm{PEO}^{10}$ & $\mathrm{DMF}^{5}$ & $\begin{array}{l}\text { Lignin } \\
\text { conc.: } 26-32 \% \text { PEO } \\
\text { conc.: } 0.2 \%\end{array}$ & - & 15 & - & 20 & 22 & Dallmeyer et al., 2013, 2014 \\
\hline $\begin{array}{l}\text { Fractionated } \\
S K L^{9}\end{array}$ & PEO 10 & $\mathrm{DMF}^{5}$ & $\begin{array}{l}\text { 99/1, 1\% PEO and } \\
\text { 1, 4, 6\% MWNTs }\end{array}$ & 25 & 15 & 0.03 & 18 & 21 & Teng et al., 2013 \\
\hline Lignin $^{11}$ & PAN $^{8}$ & $\mathrm{DMF}^{5}$ & $\begin{array}{l}\text { 0/100, 30/70, } \\
50 / 50\end{array}$ & 12 & 15 & 0.02 & 10 & - & Choi et al., 2013 \\
\hline $\begin{array}{l}\text { Organosolv } \\
\text { lignin }\end{array}$ & $\begin{array}{l}\text { PEO }^{4}, \\
\text { PAN }^{8}\end{array}$ & $\mathrm{DMF}^{5}$ & $\begin{array}{l}90 / 10(99 / 1 \text { to } \\
80 / 20)\end{array}$ & 24 & $6.5-7$ & 0.017 & 10 & 22 & Wang et al., 2013 \\
\hline Alkali Lignin ${ }^{12}$ & $\mathrm{PEO}^{4}$ & Water & $\begin{array}{l}\text { 7.4/2.6, 8.6/1.4, } \\
\text { 9/1.Lig./PEO:9/1): } \\
\text { 0.1, 0.3, 0.5 }\end{array}$ & 10.811 .710 & $10-15$ & 0.017 & $12-20$ & 24 & Hu and Hsieh, 2013; Hu et al., 2014 \\
\hline Lignin $^{11}$ & $\mathrm{PVA}^{13}$ & Water & $\begin{array}{l}30 / 70,50 / 50 \\
70 / 30\end{array}$ & $9-12$ & 26 & 0.02 & 25 & 22 & Lai et al., 2014a,b \\
\hline Lignin $^{11}$ & $\mathrm{PVA}^{13}$ & Water & $\begin{array}{l}20,50,75 \% \text { lignin. } \\
5,10 \text {, and } 15 \text { wt } \% \\
\text { CNC added to } \\
20 / 80 \text { and } 75 / 25 \text {. }\end{array}$ & $\begin{array}{l}\text { PVA solution: } 5 \\
\text { or } 8 w t \%\end{array}$ & 19 & 0.008 & 22 & 22 & Ago et al., 2012a,b, 2013 \\
\hline $\begin{array}{l}\text { Sodium } \\
\text { carbonate lignin }\end{array}$ & $\begin{array}{l}\text { Chitosan } \\
\text { PEO }^{14}\end{array}$ & $\begin{array}{l}\text { Acetic acid, } \\
\text { water }\end{array}$ & $\begin{array}{l}0.6 \% \text { PEO, } 1.5 \% \\
\text { chitosan and } 1.5,2 \text {, } \\
2.5 \text {, or } 3.0 \% \text { lignin }\end{array}$ & & 14 & 0.002 & 22.5 & 24 & Schreiber et al., 2014 \\
\hline $\begin{array}{l}\text { Hardwood } \\
\text { organosolv } \\
\text { lignin }\end{array}$ & $\begin{array}{l}\text { Cellulose } \\
\text { acetate }\end{array}$ & $\begin{array}{l}\text { Acetone, } \\
\text { DMAc }{ }^{15}\end{array}$ & $\begin{array}{l}1 / 1,2 / 1,3 / 1,4 / 1 \\
5 / 1\end{array}$ & 30 & $16-18$ & 0.01 & 22.5 & 24 & Schreiber et al., 2015 \\
\hline $\mathrm{SKL}^{1}$ & PEO ${ }^{14,16}$ & $\begin{array}{l}\mathrm{DMF}^{5}, \mathrm{NaOH} / \\
\mathrm{H}_{2} \mathrm{O}\end{array}$ & $95 / 5,97 / 3$ & $5,7,9,11$ & 20 & 0.003 & 22 & 24 & Poursorkhabi et al., 2015 \\
\hline Lignin $^{11}$ & PAN $^{8}$ & $\mathrm{DMF}^{5}$ & $1 / 1$ & 15 & 17 & 0.002 & 25 & 17 & Xu et al., 2014 \\
\hline
\end{tabular}


TABLE 1 | Continued

\begin{tabular}{|c|c|c|c|c|c|c|c|c|c|}
\hline \multicolumn{3}{|c|}{ Material } & \multicolumn{2}{|c|}{ Solution composition } & \multicolumn{4}{|c|}{ Spinning conditions } & \multirow[t]{2}{*}{ References } \\
\hline Lignin type & $\begin{array}{l}\text { Binder } \\
\text { polymer }\end{array}$ & Solvent & $\begin{array}{l}\text { Lignin/Binder } \\
\text { polymer (wt/wt\%) }\end{array}$ & $\begin{array}{l}\text { Total polymer } \\
\text { conc. (wt/v\%) }\end{array}$ & $\begin{array}{l}\text { Voltage } \\
\text { (kV) }\end{array}$ & $\begin{array}{l}\text { Feed rate } \\
(\mathrm{mL} / \mathrm{min})\end{array}$ & $\begin{array}{l}\text { Distance } \\
\text { (cm) }\end{array}$ & $\begin{array}{l}\text { Needle } \\
\text { gauge }\end{array}$ & \\
\hline Kraft lignin & $\begin{array}{l}\mathrm{PEO}^{17} \text {, soy } \\
\text { protein or } \\
\text { glycinin, }\end{array}$ & $\begin{array}{l}10 \text { vol-\% } \\
\text { acetonitrile } \\
\text { in } 0.1 \mathrm{~N} \\
\mathrm{NaOH}\end{array}$ & $\begin{array}{l}\text { PEO: } 10 \% \text { of soy: } \\
78,50,33,22\end{array}$ & 8 & 15 & 0.008 & 22 & 22 & Salas et al., 2014 \\
\hline $\begin{array}{l}\text { Lignin-phenol- } \\
\text { formaldehyde } \\
\text { resin }\end{array}$ & $\begin{array}{l}\text { Polyvinyl- } \\
\text { pyrrolidone }\end{array}$ & $\mathrm{DMF}^{5}$ & $3 / 1$ & 30 & 24 & 0.0065 & 30 & - & Guo et al., 2015 \\
\hline $\begin{array}{l}\text { Kraft } \\
\text { lignin-g-PAN }\end{array}$ & - & $\mathrm{DMF}^{5}$ & - & $15-18$ wt\% & $9-11$ & $\begin{array}{c}0.00085- \\
0.0105\end{array}$ & 15 & 18 & Youe et al., 2015 \\
\hline $\begin{array}{l}\text { Hardwood } \\
\text { organosolv } \\
\text { lignin }\end{array}$ & PAN $^{8}$ & $\mathrm{DMF}^{5}$ & $10 / 90$ to $100 / 0$ & $18-55$ & $10-15$ & $0.01-0.07$ & 15 & 21 & Oroumei et al., 2015 \\
\hline$S K L^{1}$ & $\mathrm{PEO}^{4}$ & $\mathrm{DMF}^{5}$ & \multicolumn{2}{|c|}{ Lignin: 30 wt\% PEO: 0.2 wt\% } & 15 & 0.03 & 20 & - & Gao et al., 2015 \\
\hline Alkali lignin & $\begin{array}{l}\text { PAN }^{8} \\
\text { PVA }^{13}\end{array}$ & $\mathrm{DMF}^{5}$ & \multicolumn{2}{|c|}{$\begin{array}{l}10 \text { wt } \% \text { of PAN in DMF, } 12 \text { wt } \% \text { lignin in } \\
\text { PVA (lignin/PVA } 70 / 30 \text { wt.\%) }\end{array}$} & 16 and 26 & $0.016-0.02$ & 26 & 25 & Beck et al., 2017 \\
\hline $\begin{array}{l}\text { Sulfur-free } \\
\text { Softwood } \\
\text { Lignin (SFSL) }\end{array}$ & $\mathrm{PEO}^{10}$ & $\mathrm{DMF}^{5}$ & \multicolumn{2}{|c|}{$\begin{array}{l}30 \text { wt } \% \text { in PEO/SFSL/DMF, with PEO/SFSL } \\
\text { ratio of } 1 / 99\end{array}$} & $\begin{array}{c}70 \times 10^{3} \\
\mathrm{~V} / \mathrm{m}\end{array}$ & $\begin{array}{l}4.2 \times 10^{-10} \\
\mathrm{~m}^{3} \mathrm{~s}^{-1}\end{array}$ & 20 & 20 & Aslanzadeh et al., 2017 \\
\hline $\begin{array}{l}\text { Extracted lignin } \\
\text { from corn stalk }\end{array}$ & $\mathrm{PEO}^{16}$ & $\mathrm{DMF}^{5}$ & \multicolumn{2}{|c|}{$\begin{array}{l}30 \text { wt } \% \text { in DMF with a ratio of lignin to PEO } \\
\text { as } 95: 5 \text { wt. } \% \text {. }\end{array}$} & 20 & 0.0083 & 20 & 20 & Shi et al., 2018 \\
\hline $\begin{array}{l}\text { Kraft lignin from } \\
\text { FP Innovation }\end{array}$ & $\mathrm{PEO}^{10}$ & $\mathrm{DMF}^{5}$ & \multicolumn{2}{|c|}{$\begin{array}{l}\text { Lignin/PEO (99/1 w/w), zeolite/lignin = 1-5 } \\
\text { wt\% }\end{array}$} & 12 & 0.02 & 15 & $18-25$ & Bahi et al., 2017 \\
\hline $\begin{array}{l}\text { Alkali lignin } \\
(\mathrm{Mv}=5000- \\
6000)\end{array}$ & $\begin{array}{c}\text { (PZAA@ }^{\text {PNTs) }}{ }^{18}, \\
\text { PEO }^{4}\end{array}$ & $\mathrm{DMF}^{5}$ & \multicolumn{2}{|c|}{$\begin{array}{l}\text { Lignin/PEO weight ratio of 96:4 0.5-2 wt\% } \\
\text { PZAA@CNTs }\end{array}$} & 40 & $20 \mu \mathrm{L} / \min$ & 15 & 19 & Liu et al., 2020 \\
\hline Alkali lignin (AL) & $\mathrm{PVA}^{19}$ & $\begin{array}{l}\mathrm{NaOH} / \\
\text { water }\end{array}$ & \multicolumn{2}{|c|}{$\begin{array}{l}15 \mathrm{wt} \% \text {.PVA, } \mathrm{AL} \text { in } 1 \mathrm{M} \mathrm{NaOH} \text { to } 15 \mathrm{wt} \% \\
\mathrm{AL}, 3: 7 \text { and } 5: 5 \mathrm{AL}: \mathrm{PVA}\end{array}$} & $10-25$ & $\begin{array}{c}0.00083- \\
0.01\end{array}$ & $\begin{array}{c}10-20 \\
\mathrm{~cm}\end{array}$ & 20 & Camiré et al., 2020 \\
\hline $\begin{array}{l}\text { Alkali lignin } \\
(\mathrm{AL})^{13}\end{array}$ & $\mathrm{PVA}^{20}$ & Water & \multicolumn{2}{|l|}{ AL: PVA 75:25. } & 17 & 0.0083 & 20 & - & Wei J. et al., 2019 \\
\hline Alkali lignin & $\mathrm{PVA}^{21}$ & Water & \multicolumn{2}{|l|}{ Lignin/PVA (10 wt\%.) } & 20 & 0.08 & 20 & 22 & Zhang et al., 2019 \\
\hline $\begin{array}{l}\text { Fractionation } \\
\mathrm{SKL}^{1}\end{array}$ & $\begin{array}{l}\text { PEO } 22 \\
\text { NCCs }\end{array}$ & $\mathrm{DMF}^{5}$ & \multicolumn{2}{|c|}{$\begin{array}{l}27 \text { wt.\%. lignin, } 1 \text { wt.\% PEO, } 5 \text { wt.\% NCC } \\
\text { in MF }\end{array}$} & +20 & 0.01 & 20 & 20 & Cho et al., 2019b \\
\hline $\begin{array}{l}\text { fractionation of } \\
\mathrm{SKL}^{1}\end{array}$ & $\begin{array}{l}\mathrm{PEO}^{22} \\
\text { NCCs }\end{array}$ & DMF & \multicolumn{2}{|c|}{$\begin{array}{l}25-30 \text { wt.\%. lignin, } 1 \text { wt.\% PEO, 1-5 wt\% } \\
\text { NCC in DMF }\end{array}$} & +20 & $0.01-0.03$ & $20-30$ & 25 & Cho et al., 2017 \\
\hline $\begin{array}{l}\text { Kraft lignin } \\
\text { nanoparticle } \\
(\mathrm{KLN})^{23}\end{array}$ & $\begin{array}{l}\text { PVA }^{21} \\
\text { PGS }\end{array}$ & $\begin{array}{l}75: 25 \text { of } \\
\mathrm{H}_{2} \mathrm{O} \text { and } \\
\text { DMF }\end{array}$ & \multicolumn{2}{|c|}{$\begin{array}{l}18 \% \text { w/v DMF at } 40: 60 \text { wt. } \% \text { of } \\
\text { PVA-pPGS, 0-5 wt } \% \text { lignin }\end{array}$} & 19 & 0.0083 & 30 & 21 & Saudi et al., 2019 \\
\hline
\end{tabular}


TABLE 1 | Continued

\begin{tabular}{|c|c|c|c|c|c|c|c|c|c|}
\hline \multicolumn{3}{|c|}{ Material } & \multicolumn{2}{|c|}{ Solution composition } & \multicolumn{4}{|c|}{ Spinning conditions } & \multirow[t]{2}{*}{ References } \\
\hline Lignin type & $\begin{array}{l}\text { Binder } \\
\text { polymer }\end{array}$ & Solvent & $\begin{array}{l}\text { Lignin/Binder } \\
\text { polymer (wt/wt\%) }\end{array}$ & $\begin{array}{l}\text { Total polymer } \\
\text { conc. (wt/v\%) }\end{array}$ & $\begin{array}{l}\text { Voltage } \\
\text { (kV) }\end{array}$ & $\begin{array}{l}\text { Feed rate } \\
(\mathrm{mL} / \mathrm{min})\end{array}$ & $\begin{array}{l}\text { Distance } \\
(\mathrm{cm})\end{array}$ & $\begin{array}{l}\text { Needle } \\
\text { gauge }\end{array}$ & \\
\hline $\begin{array}{l}\text { Lignin extracted } \\
\text { from cornstalk } \\
\text { residues }\end{array}$ & PAN, GN24 & $\mathrm{DMF}^{5}$ & \multicolumn{2}{|c|}{$0.05-0.3 w t . \%$ GNs, 20 wt.\% PAN } & 15 & 0.0167 & 15 & - & Dai et al., 2019 \\
\hline Lignin (L) $)^{25}$ & $\begin{array}{l}\text { PLA, TPU, } \\
\text { MDI }^{26}\end{array}$ & THF, DMF & \multicolumn{2}{|c|}{$\begin{array}{l}\text { ᄂ/20-50\%PLA+7\%MDI in THF/DMF (1:1), } \\
\text { L/20-50\%TPU+7\%MDI in DMF }\end{array}$} & 7.7 & $30 \mu \mathrm{L} \cdot \mathrm{min}^{-1}$ & 10 & - & Culebras et al., 2019 \\
\hline Kraft lignin ${ }^{11}$ & PAN $^{8}$ & $\mathrm{DMF}^{5}$ & \multicolumn{2}{|c|}{$\begin{array}{l}\text { PAN:Lignin } 90: 10,80: 20 \text { and } 70: 30 \text { wt.\%) } \\
\text { in } 10 \% \text { solution }\end{array}$} & 19 & 0.0133 & 16 & - & Perera Jayawickramage et al., 2019 \\
\hline Alkali lignin & PVA & Acetic acid & \multicolumn{2}{|c|}{$\begin{array}{l}10 \mathrm{wt} \% \text { PVA, Lignin, PVA soln., and acetic } \\
\text { acid = 1:1:3(w/v/v) }\end{array}$} & 18 & 0.4 & - & 22 & Song et al., 2017, 2019; Meng et al., 2019 \\
\hline $\begin{array}{l}\text { Hardwood } \\
\text { lignin }\end{array}$ & $\begin{array}{l}\text { Pitch, PAN, } \\
\text { zinc } \\
\text { acetate }\end{array}$ & $\mathrm{DMF}^{5}$, THF & \multicolumn{2}{|c|}{$\begin{array}{l}\text { PAN:lignin } 9: 1,20 w t \% \text { of pitch in THF to } \\
\text { achieve PAN/pitch } 7 / 3 w t \% \text {. zinc acetate } \\
(3,5,10 w t . \%)\end{array}$} & - & - & - & - & Yun et al., 2019 \\
\hline Kraft lignin ${ }^{11}$ & $\mathrm{rPET}^{27}$ & $\begin{array}{l}\text { Trifluoroacetic } \\
\text { acid }\end{array}$ & \multicolumn{2}{|c|}{ Lignin 20-50\%, Conc. (15-25 w/v), } & 20-30 & $\begin{array}{l}0.1-2 \\
\mu L / \mathrm{min}\end{array}$ & $\begin{array}{l}7,13.5 \\
20\end{array}$ & 21 & Svinterikos and Zuburtikudis, 2017; Svinterikos et al., 2019 \\
\hline $\begin{array}{l}\text { Biorefinery } \\
\text { lignin } \\
\text { (Protobind } \\
2400)\end{array}$ & $\begin{array}{l}\text { PAN }^{28} \\
\text { GRP }^{29}\end{array}$ & $\mathrm{DMF}^{5}$ & \multicolumn{2}{|c|}{$\begin{array}{l}\text { 1, 5\% GRP, } 20 \text { wt. } \% \text { PAN, Lignin: PAN } \\
50: 50,25: 75,15: 85\end{array}$} & 24 & 0.005 & & 22 & Demiroğlu Mustafov et al., 2019 \\
\hline $\begin{array}{l}50 \text { wt } \% \\
\text { fractionated } \\
\text { hardwood Kraft } \\
\text { lignin }\end{array}$ & - & $\mathrm{DMF}^{5}$ & \multicolumn{2}{|l|}{-} & - & 0.0166 & 13 & 22 & Schlee et al., 2019b \\
\hline $\begin{array}{l}\text { Kraft lignin } \\
\text { (Indulin AT) }\end{array}$ & $\mathrm{PVA}^{30}$ & DMSO & \multicolumn{2}{|c|}{ DMSO with conc. 3 to $15 \mathrm{wt} \%$} & $15-20$ & 0.00833 & 20 & 21 & Roman et al., 2019 \\
\hline Kraft lignin & $\mathrm{PEO}^{22}$ & $\begin{array}{l}1 \mathrm{M} \mathrm{NaOH} \\
\mathrm{NaNO}_{3}\end{array}$ & \multicolumn{2}{|c|}{$\begin{array}{l}10-50 \mathrm{~mol} \% \mathrm{NaNO}_{3} / \text { polymer. PEO/lignin } \\
\text { in } 1 \mathrm{M} \mathrm{NaOH} \text {. Polymer was } 12 \mathrm{wt} \%\end{array}$} & $19-24$ & 0.0166 & 18,20 & 23 & Schlee et al., 2019a \\
\hline Alkali lignin ${ }^{11}$ & PVA & Water & \multicolumn{2}{|c|}{ Lignin in $\mathrm{H}_{2} \mathrm{O}$ then add $\mathrm{PVA}$} & 26 & 0.02 & 25 & 18 & Ma et al., 2019 \\
\hline $\mathrm{OL}^{31}$ & PAN $^{8}$ & $\mathrm{DMF}^{5}$ & \multicolumn{2}{|c|}{ PAN:lignin 10:0, 7:3, 5:5, 3:7 wt.\% } & - & $10 \mu \mathrm{L} \min ^{-1}$ & 15 & 20 & Dalton et al., 2019 \\
\hline Kraft Lignin (KL) & $\begin{array}{l}\text { cellulose } \\
\text { acetate } \\
\text { (CA) }\end{array}$ & $\begin{array}{l}\text { Acetone, } \\
\mathrm{N}, \mathrm{N}- \\
\text { dimethyl } \\
\text { cyclohexylamine }\end{array}$ & \multicolumn{2}{|c|}{$\begin{array}{l}\text { KL:CA } 1: 1 \text { with conc. } 8 \text { wt. } \% \text { in solvent }(2: 1 \\
\mathrm{V} / \mathrm{v}) \text {. }\end{array}$} & 20 & 0.0125 & 20 & - & Jia et al., 2018 \\
\hline
\end{tabular}


TABLE 1 | Continued

\begin{tabular}{|c|c|c|c|c|c|c|c|c|c|}
\hline \multicolumn{3}{|c|}{ Material } & \multicolumn{2}{|c|}{ Solution composition } & \multicolumn{4}{|c|}{ Spinning conditions } & \multirow[t]{2}{*}{ References } \\
\hline Lignin type & $\begin{array}{l}\text { Binder } \\
\text { polymer }\end{array}$ & Solvent & $\begin{array}{l}\text { Lignin/Binder } \\
\text { polymer (wt/wt\%) }\end{array}$ & $\begin{array}{l}\text { Total polymer } \\
\text { conc. (wt/v\%) }\end{array}$ & $\begin{array}{l}\text { Voltage } \\
\text { (kV) }\end{array}$ & $\begin{array}{l}\text { Feed rate } \\
(\mathrm{mL} / \mathrm{min})\end{array}$ & $\begin{array}{l}\text { Distance } \\
(\mathrm{cm})\end{array}$ & $\begin{array}{l}\text { Needle } \\
\text { gauge }\end{array}$ & \\
\hline Lignin $^{11}$ & $\mathrm{PVA}^{36}$ & Water & \multicolumn{2}{|l|}{5 wt\% PVA solution } & $15-20$ & 0.01666 & 20 & 22 & Zhao et al., 2018 \\
\hline $\begin{array}{l}\text { Lignin extracted } \\
\text { from Acacia } \\
\text { wood powder }\end{array}$ & $\begin{array}{l}\mathrm{PVA}^{32} \\
\mathrm{AgNO}_{3}\end{array}$ & $\begin{array}{l}\text { Methanol, } \\
\text { water }\end{array}$ & \multicolumn{2}{|c|}{ PVA:lignin 9:1 in methanol: $\mathrm{H}_{2} \mathrm{O}(60: 40)$} & 15 & 10 & 12 & 22 & Aadil et al., 2018 \\
\hline $\begin{array}{l}\text { Solvent } \\
\text { fractionated } \\
\text { Softwood kraft } \\
\text { lignin, Indulin } \\
\text { AT }\end{array}$ & $\mathrm{PEO}^{22}$ & Water & \multicolumn{2}{|c|}{$\mathrm{H}_{2} \mathrm{O}$ at conc. $(0.1-0.3 \mathrm{wt} \%)$. } & $25-30$ & 0.01 & 25 & - & Cho et al., 2018 \\
\hline Alkali lignin & PVP33 & $\mathrm{DMF}^{5}$ & \multicolumn{2}{|c|}{$\begin{array}{l}\mathrm{Mg}\left(\mathrm{NO}_{3}\right)_{2} \cdot 6 \mathrm{H}_{2} \mathrm{O} / \text { lignin } 0.5: 1,1: 1 \text { and 2:1 } \\
\text { wt.\% }\end{array}$} & 15 & 0.0033 & 15 & - & Ma et al., 2018 \\
\hline $\begin{array}{l}\text { Lignin } \\
\text { containing } \\
\text { sulfur }\end{array}$ & $\begin{array}{c}\text { PVA }^{20} \\
\text { MWNTs }^{35}\end{array}$ & Water & \multicolumn{2}{|c|}{ 10\%PVA, 1 wt.\% t-MWNT } & $25-30$ & $\begin{array}{c}7- \\
10 \mu \mathrm{L} / \mathrm{min}\end{array}$ & 10 & 21 & Lee et al., 2018 \\
\hline $\begin{array}{l}\text { Extracted } \\
\text { Organosolv and } \\
\text { alkaline Lignin }\end{array}$ & $\mathrm{PEO}^{37}$ & $\mathrm{DMF}$ & \multicolumn{2}{|c|}{$\begin{array}{l}\text { Lignin/PEO } 30 \text { wt\% in DMF with lignin: PEO } \\
\text { as 95:5 wt.\%. }\end{array}$} & 20 & 0.00833 & 20 & 20 & Shi et al., 2018 \\
\hline $\begin{array}{l}\text { Alkali Lignin } \\
\text { (low sulfonate } \\
\text { content) }\end{array}$ & PAN $^{8}$ & $\mathrm{DMF}$ & \multicolumn{2}{|c|}{$\begin{array}{l}\text { PAN:lignin } 12 \text { and } 18 \text { wt\%, PAN/lignin: } \\
\text { 80/20, 50/50 }\end{array}$} & 8.5 & - & 20 & - & Lei et al., 2017 \\
\hline Lignin $^{11}$ & $\begin{array}{l}\text { PVA }^{13} \\
\text { Surfactant }\end{array}$ & Water & \multicolumn{2}{|c|}{$\begin{array}{l}\text { Lignin: PVA in } \mathrm{H}_{2} \mathrm{O} \text {, Surfactant mass: } \\
0.2-1.2 \text {. }\end{array}$} & 22 & 0.0166 & 15 & 22 & Fang et al., 2017b \\
\hline Lignin $^{11}$ & PAN $^{8}$ & $\begin{array}{l}\text { DMF, } \\
\text { Pluronic } \\
\text { P123 }\end{array}$ & \multicolumn{2}{|c|}{$\begin{array}{l}88 \text { wt } \% \text { PAN in DMF added to PAN/lignin } \\
\text { was 1:1 }\end{array}$} & 20 & 0.025 & 15 & - & Shi et al., 2017 \\
\hline \multicolumn{10}{|c|}{ Co- electrospinning } \\
\hline Shell solution & \multicolumn{2}{|c|}{ Core solution } & \multicolumn{2}{|c|}{ Voltage (kV) } & Feed rate & & $\begin{array}{l}\text { Distance } \\
\text { (cm) }\end{array}$ & $\begin{array}{l}\text { Needle } \\
\text { gauge }\end{array}$ & References \\
\hline Ethanol & \multicolumn{2}{|c|}{ Alcell lignin/ethanol: 1/1 w/w } & \multicolumn{2}{|c|}{12} & $\begin{array}{l}10 \% \text { of lignin } \\
\text { solution }\end{array}$ & & $20-25$ & - & Lallave et al., 2007 \\
\hline Ethanol & \multicolumn{2}{|c|}{$\begin{array}{l}\text { Alcell lignin/ethanol: 1/1 w/w Inner core: } \\
\text { glycerine }\end{array}$} & \multicolumn{2}{|c|}{12} & $\begin{array}{l}\text { Ethanol/lignin/ } \\
\text { glycerine: } \\
0.05 / 0.5 / 0.01 \text { to } \\
0.1 / 1 / 0.25 \mathrm{~mL} / \mathrm{h}\end{array}$ & & $20-25$ & - & Lallave et al., 2007 \\
\hline Ethanol & \multicolumn{2}{|c|}{ Alcell lignin/ethanol: 45/55 w/w\% } & \multicolumn{2}{|c|}{12} & $\begin{array}{l}\text { Ethanol: } 0.1 \mathrm{~mL} / \mathrm{h} \\
\text { lignin solution: } \\
1 \mathrm{~mL} / \mathrm{h}\end{array}$ & & 30 & - & Berenguer et al., 2015 \\
\hline
\end{tabular}


TABLE 1 | Continued

\begin{tabular}{|c|c|c|c|c|c|c|c|c|c|}
\hline \multicolumn{3}{|c|}{ Material } & \multicolumn{2}{|c|}{ Solution composition } & \multicolumn{4}{|c|}{ Spinning conditions } & \multirow[t]{2}{*}{ References } \\
\hline Lignin type & $\begin{array}{l}\text { Binder } \\
\text { polymer }\end{array}$ & Solvent & $\begin{array}{l}\text { Lignin/Binder } \\
\text { polymer (wt/wt\%) }\end{array}$ & $\begin{array}{l}\text { Total polymer } \\
\text { conc. (wt/v\%) }\end{array}$ & $\begin{array}{l}\text { Voltage } \\
\text { (kV) }\end{array}$ & $\begin{array}{l}\text { Feed rate } \\
(\mathrm{mL} / \mathrm{min})\end{array}$ & $\begin{array}{l}\text { Distance } \\
\text { (cm) }\end{array}$ & $\begin{array}{l}\text { Needle } \\
\text { gauge }\end{array}$ & \\
\hline Ethanol & \multicolumn{3}{|c|}{$\begin{array}{l}\text { Lignin/ethanol/platinum acetyl acetonate: } \\
1 / 1 / 0.002 \text { and } 1 / 1 / 0.004 \mathrm{w} / \mathrm{w}\end{array}$} & 12 & $\begin{array}{l}\text { Ethanol: } \\
0.001 \mathrm{~mL} / \mathrm{min} \\
\text { Lignin: } \\
0.014 \mathrm{~mL} / \mathrm{min}\end{array}$ & & $20-25$ & - & Ruiz-Rosas et al., 2010b \\
\hline $\begin{array}{l}\text { sol-gel } \\
\text { Alkoxide }\end{array}$ & \multicolumn{2}{|c|}{ Alcell lignin/Ethanol: 1/1 w/w } & & Not specified & $\begin{array}{l}\text { Core: } \\
0.067 \mathrm{~mL} / \mathrm{min} \\
\text { Shell: } \\
0.008 \mathrm{~mL} / \mathrm{min}\end{array}$ & & $\begin{array}{l}\text { Not } \\
\text { specified }\end{array}$ & - & Ruiz-Rosas et al., 2010a \\
\hline $\begin{array}{l}\text { 17\% Alkali kraft } \\
\text { lignin } \\
\text { (Aldrich)/PAN): } \\
1 / 1\end{array}$ & \multicolumn{2}{|c|}{$\begin{array}{l}\text { Acetylated cellulose nanofiber/silicone oil/ } \\
\text { chloroform mixture }\end{array}$} & & 17 & $\begin{array}{l}\text { Core and shell: } \\
0.03 \mathrm{~mL} / \mathrm{h}\end{array}$ & & $\sim 20$ & $\begin{array}{l}\text { Inner:19 } \\
\text { Outer: } \\
15\end{array}$ & Xu et al., 2013 \\
\hline $\begin{array}{l}17 \% \text { Alkali kraft } \\
\text { lignin } \\
\text { (Aldrich)/PAN): } \\
1 / 1\end{array}$ & \multicolumn{2}{|c|}{ Pure glycerin } & & 17 & $\begin{array}{l}\text { Core and shell: } \\
0.03 \mathrm{~mL} / \mathrm{h}\end{array}$ & & $\sim 20$ & $\begin{array}{l}\text { Inner:19 } \\
\text { Outer: } \\
15\end{array}$ & Xu et al., 2013 \\
\hline $\begin{array}{l}\text { Acetic acid } \\
\text { lignin and PEO } \\
\text { in DMF, } \\
\text { Fe(Acac) } \\
\text { additive in the } \\
\text { shell }{ }^{34}\end{array}$ & \multicolumn{2}{|c|}{35 wt $\%$ of SAN ${ }^{34}$ dissolved in DMF } & & $25-30$ & $\begin{array}{l}\text { Core: } 0.4 \mathrm{~mL} / \mathrm{h} \\
\text { Shell: } 1 \mathrm{~mL} / \mathrm{h}\end{array}$ & & $15-20$ & - & Yu et al., 2018 \\
\hline Ethanol & \multicolumn{3}{|c|}{$\begin{array}{l}\mathrm{H}_{3} \mathrm{PO}_{4} / \text { lignin, } \mathrm{H}_{3} \mathrm{PO}_{4}(85 \text { wt.\%) /lignin } \\
\text { /ethanol (0.3/1/1 weight ratio) }\end{array}$} & 24 & $\begin{array}{l}\text { Core: } 3 \mathrm{~cm}^{3} \mathrm{~h}^{-1} \\
\text { Shell: } 0.3 \mathrm{~cm}^{3} \mathrm{~h}^{-1}\end{array}$ & & - & 30 & García-Mateos et al., 2018 \\
\hline Ethanol & \multicolumn{3}{|c|}{$\begin{array}{l}\text { 1:1 Lignin:ethanol, lignin: ethanol: } \mathrm{H}_{3} \mathrm{PO}_{4} \\
(1: 1: 0.3) \text {, platinum acetylacetonate:lignin } \\
0.006: 1 \text { and } 0.03: 1\end{array}$} & 14 and 22 & $\begin{array}{l}\text { Core: } 0.0016 \text {, } \\
0.005 \text { Shell: } \\
0.0166,0.05\end{array}$ & & 25 & - & García-Mateos et al., 2017 \\
\hline
\end{tabular}

${ }^{1}$ SKL, Softwood kraft lignin (Indulin-AT); ${ }^{2} \mathrm{HKL}$, Hardwood kraft lignin; ${ }^{3} \mathrm{SOL}$, Softwood organosolv lignin; ${ }^{4} \mathrm{PEO}$ with M.W. $=600 \mathrm{~K}$ g/mol; ${ }^{5} \mathrm{~N}, \mathrm{~N}$-dimethyl formamide; ${ }^{6}$ SulKL, Sulfonated kraft lignin; ${ }^{7} \mathrm{LS}$, Lignosulfonate; ${ }^{8} \mathrm{PAN}$ with M.W. $=150-160 \mathrm{~K} \mathrm{~g} / \mathrm{mol} ;{ }^{9}$ Fractionated SKL to a low M.W. fraction $\left(M_{W}=6800, M_{n}=3000\right)$ and a high M.W. fraction $\left(M_{W}=35,000, M_{n}=9000\right) ; 10 P E O$ with M.W. = 1000K g/mol; 11 Lignin (M.W. = 10,000 g/mol, Sigma-Aldrich); ${ }^{12}$ Alkali Lignin (M.W. =60,000 g/mol, Sigma-Aldrich); ${ }^{13}$ Poly (vinyl alcohol) (PVA) M.W. = 85K to $124 \mathrm{~K} ;{ }^{14} \mathrm{PEO}$ with M.W. = 5000K g/mol; ${ }^{15} \mathrm{~N}, \mathrm{~N}$-dimethylacetamide; ${ }^{16} \mathrm{PEO}$ with M.W. = 200K g/mol, ${ }^{17} \mathrm{PEO}$ with M.W. = 400K g/mol, ${ }^{18} \mathrm{PZAA} @ \mathrm{CNTs}$ : cross-linked polyphosphazene-functionalized carbon nanotubes, ${ }^{19} \mathrm{PVA}$ with M.W. = 28,000 Da and 31,000-50,000 Da, 20PVA with M.W = 89,000-98,000, Sigma-Aldrich), ${ }^{21}$ PVA with M.W = 145,000-195,000 and PGS: poly(glycerol sebacate), ${ }^{22}$ PEO with MW of $1 \times 10^{6} \mathrm{~g} / \mathrm{mol}$ and NCCs: nanocrystalline celluloses, ${ }^{23} \mathrm{KLN}$, Kraft lignin nanoparticle (particle size $~ 90 \mathrm{~nm}, \mathrm{Mw}=9000$, Sigma-Aldrich, ${ }^{24} \mathrm{GN}$, Graphene nanosheet (average thickness < $30 \mathrm{~nm}$, specific surface area $\sim 60 \mathrm{~m}^{2} \mathrm{~g}^{-1}$ ), ${ }^{25} \mathrm{Lignin}$ : Alcell Organosolv hardwood lignin, ${ }^{26} \mathrm{PLA}$ : (3001D), TPU: thermoplastic elastomeric polyurethane, MPI: 7\%Methylenediphenyl diisocyanate, ${ }^{27}$ rPET: Waste water-bottles were used as the source of PET, ${ }^{28}$ Polyacrylonitrile (PAN) with MW 80,000 g/mol, ${ }^{29} \mathrm{GRP}$ : graphene with an average thickness of $12 \mathrm{~nm},{ }^{3}$ PVA with a MW $=130000 \mathrm{~g} \cdot \mathrm{mol}^{-1}$ and a degree of hydrolysis of 86-89\% was obtained from Sigma-Aldrich under the trade name of Mowiol 18-88, ${ }^{31}$ OL: Organosolv Lignin (Lignin, MW $=4000 \mathrm{~g} \mathrm{~mol}^{-1}$ ), ${ }^{32}$ PVA: Poly(vinyl alcohol) (PVA) (Mw: 30,000-70,000), ${ }^{33}$ PVP: Polyvinylpyrrolidone (PVP, MW = 1,300,000), ${ }^{34}$ PEO with MW = 300,000, iron(III) acetylacetonate (Fe(acac) 3 ), (SAN) Poly(styreneco-acrylonitrile), ${ }^{35}, t-M W N T s:$ thin multi-walled carbon nanotubes, ${ }^{36}$ PVA with molecular weight of 117,000 and hydrolysis degree of 87-89\%, Sigma-Aldrich, ${ }^{37}$ PEO: with M.W. = 2000 Kg/mol, ${ }^{38}$ Surfactant: Anionic surfactant sodium dodecyl sulfate (SDS), Cationic surfactant N,N,N-trimethyl-1dodecanaminium bromide (DTAB), Nonionic surfactant Triton X-100 (TX-100) from Sigma-Aldrich. 
known as carbonization, is to obtain the final carbonized fibers (Ruiz-Rosas et al., 2010b).

Stabilization time is an essential task for industrial carbon fiber production. Depending on the scale of the process, Alcell lignin can take several days (Mainka et al., 2015a). This is due to the devolatilization of lignin which increases the stabilization time. Studies showed that the thermal stabilization of softwood lignin was achieved in a shorter time compared to hardwood lignin (Norberg et al., 2013). However, softwood lignin has lower spinability than hardwood lignin due to the high melting point and cross-linked structure of softwood lignin (Zhang and Ogale, 2014; Cho et al., 2019a). Moreover, studies have shown that lignin fibers containing certain amounts of $\mathrm{NaOH}$ or $\mathrm{KOH}$ do not require this thermostabilization step. They can be directly carbonized at a low heating rate without having to fuse fibers (Hu and Hsieh, 2013; Poursorkhabi et al., 2016; Schlee et al., 2019a).

Several temperatures and heating rates have been applied for lignin as well as rapid variations in the total oxygen, hydrogen, carbon and mass content above $190^{\circ} \mathrm{C}$ (Braun et al., 2005). It is proposed that thermal decomposition of lignin starts with hemolytic dissociation of the weakest bond ( $\beta$-O-4 linkage) (Britt et al., 1995, 2000a,b; Fang et al., 2017a). Decomposition continues by a variety of oxidation, rearrangement and elimination reactions initiated by the radicals. Hemolysis of $-\mathrm{OCH}_{3}$ (methoxyl) groups require a slower rate at higher temperatures. The extent and rate of decomposition depend on factors like temperature, heating rate, and oxygen content. Besides hemolysis, autooxidation is an alternative reaction that occurs in the existence of air and forms carbonyl and carboxyl groups on the lignin structure (Fenner and Lephardt, 1981; Braun et al., 2005). For temperatures up to $200-250^{\circ} \mathrm{C}$, the formation of carboxyl and carbonyl groups increase the oxygen content of the fiber. At higher temperatures, these functional groups lose oxygen and form anhydrides, esters and crosslinks inside the structures of lignin. At temperatures above $250^{\circ} \mathrm{C}$, carbon-carbon aromatic bonds are produced which is suited for stronger materials ( $\mathrm{Hu}$ and Hsieh, 2013). There is an opposite relation among the glass transition temperature $\left(T_{g}\right)$ and the hydrogen content of lignin. For example, materials with lesser hydrogen content have higher $\mathrm{T}_{g}$ (Braun et al., 2005).

Analysis of evolved gasses during the carbonization of lignin showed that the non-carbon atoms break apart the sample and evolve $\mathrm{CO}_{2}, \mathrm{CO}$ and $\mathrm{CH}_{4}$ gases as well as $\mathrm{H}_{2} \mathrm{O}$ (Yang et al., 2007; Ruiz-Rosas et al., 2010b). During carbonization, water molecules are released between 100 and $600^{\circ} \mathrm{C}$. The hydroxyl $(-\mathrm{OH})$ groups break at high temperatures, however, the moisture in the samples evolved at lower temperatures $\sim 100^{\circ} \mathrm{C} . \mathrm{CO}_{2}$ is evolved in a temperature range like water desorption. $\mathrm{CO}$ is produced in a range from 200 to $800^{\circ} \mathrm{C}$ resulting from breakage of carbonyl or carboxyl groups or char forming reactions that were dependent on the type of lignin. Chatterjee and Saito (2015) displayed that the content of lignin controlled the char yield and consequently controlled the activated carbon yield. Additionally, the microstructure of char yield depends on the source of biomass and amount of cellulose and lignin. The author showed a reduction in the char yield with increasing low molecular weight fraction of lignin. Releasing of $\mathrm{H}_{2}$ starts at temperatures above $500^{\circ} \mathrm{C}$ and reaches to around $700^{\circ} \mathrm{C}$. These gases assigned to the volatiles are produced from the reaction of hydrocarbons or depolymerization of phenyl groups (Blanco López et al., 2002; Yang et al., 2007; Ruiz-Rosas et al., 2010b; Foston et al., 2013).

The sample structure is composed primarily of condensed aryl structures at $1000{ }^{\circ} \mathrm{C}$. At temperatures assigned $\sim 1000^{\circ} \mathrm{C}$, the carbonization can sometimes degrade the aryl structures that are produced at lower temperatures (like $800^{\circ} \mathrm{C}$ ) (Foston et al., 2013). Thus, the assembly of the formed carbon fiber depends on the heating condition. The carbonization conditions which are reported in the literature have heating rates of 5 or $10^{\circ} \mathrm{C} / \mathrm{min}$ and maximum temperatures ranging from 600 to $2200^{\circ} \mathrm{C}$ with residence times at a maximum temperature between 60 and $150 \mathrm{~min}$ (Ruiz-Rosas et al., 2010b; Seo et al., 2011; Choi et al., 2013; Dallmeyer et al., 2013; Hu and Hsieh, 2013; Wang et al., 2013; Xu et al., 2013, 2014; Dallmeyer et al., 2014; Hu et al., 2014; Lai et al., 2014a,b; Guo et al., 2015; Schreiber et al., 2015). A recent study showed that the carbonization time of lignin carbon fiber decreased from 708 to $24 \mathrm{~min}$ without losing mechanical properties (Bengtsson et al., 2020). Moreover, increasing the carbonization temperature from 600 to $1600^{\circ} \mathrm{C}$, improved the modulus from 18 to $77 \mathrm{GPa}$ due to the formation of nanocrystalline graphite (Bengtsson et al., 2020). Most of the literature involves using an inert atmosphere (nitrogen and argon gas). During carbonization, the fibers are free or clamped (Teng et al., 2013) to induce stretching. Stretching of the fiber during thermal treatment by clamp will improve the orientation of the fiber and decrease the fiber diameter consequently enhancing the mechanical properties (tensile modulus $<100 \mathrm{GPa}$ ) of the fiber (Reneker and Yarin, 2008).

The yield is calculated according to fiber weight and depends on heating conditions along with the type of lignin. The carbonization conditions applied to electrospun lignin fibers are shown in Table 2. Carbonization of lignin fibers is a less energy and time-intensive process (less than $2 \mathrm{~h}$ ) than the carbonization of PAN fibers (Liu and Kumar, 2012; Baker and Rials, 2013). Bengtsson et al. (2019) showed a reduction in the time required to stabilize lignin fiber from $16 \mathrm{~h}$ to less than $2 \mathrm{~h}$ at $250^{\circ} \mathrm{C}$ due to the high carbon content of lignin (60-65\%). In the literature, the influences of carbonization temperature on characteristics of carbonized electrospun lignin fibers have been extensively studied (Ruiz-Rosas et al., 2010b; Choi et al., 2013; Dallmeyer et al., 2014; Schreiber et al., 2015). The carbonization temperature has a direct effect on the tensile characteristics of the carbon fiber (Bengtsson et al., 2020). Increasing carbonization temperature led to an enhancement of the tensile modulus, however, decreased elongation at break and reduced fiber diameter. Interestingly, the tensile strength increased till $1000^{\circ} \mathrm{C}$ and started to decrease above this temperature due to the defect on the fiber at elevated temperature (Bengtsson et al., 2020).

Hollow nano-carbon fibers were shaped by carbonization of Alcell lignin fibers collected from a tri-axial configuration on the three-layer electrospinning (co-electrospinning) (Lallave et al., 2007). Alcell lignin in ethanol solution was the middle layer, glycerine was the core, and ethanol was the outer sheath. The formation of hollow nanocarbon fiber produced 
TABLE 2 | Conditions applied to produce carbonized electrospun lignin fibers.

Thermostabilization

Carbonization

Diameter (d) of carbonized fibers

\begin{tabular}{|c|c|c|c|c|c|c|c|}
\hline Heating rate $\left({ }^{\circ} \mathrm{C} / \mathrm{min}\right)$ & $\begin{array}{l}\text { Max. } \\
\text { Temp. } \\
\left({ }^{\circ} \mathrm{C}\right)\end{array}$ & $\begin{array}{c}\text { Residence } \\
\text { time at } \\
\text { max. T (h) }\end{array}$ & Purge gas & $\begin{array}{l}\text { Heating } \\
\text { rate } \\
\left({ }^{\circ} \mathrm{C} / \mathrm{min}\right)\end{array}$ & $\begin{array}{c}\text { Max. } \\
\text { Temperature } \\
\left({ }^{\circ} \mathrm{C}\right)\end{array}$ & $\begin{array}{c}\text { Residence } \\
\text { time at } \\
\text { max. } \mathrm{T}(\mathrm{h})\end{array}$ & Purge gas \\
\hline
\end{tabular}

275

$-\quad 200$

0.4

0.5

$10^{\circ} \mathrm{C} / \mathrm{min} 0.5^{\circ} \mathrm{C} / \mathrm{min}$

No need for thermostabilizing

0.5

250

260

220

250

75

2

1

220

\section{0}

225

250

250

1

$$
15 \text { in }
$$

\section{Air}

5

900,1100

Air

Air

Air

8
1
2
1
-
1
1

Air
Air
Air
Air
Air
Air
Air

3
4
12
1
1
-
36
1

$\begin{array}{cc}\text { Air } & 5 \mathrm{~mL} / \mathrm{h} \\ \text { Air } & 3 \\ \mathrm{~N}_{2} & 5 \\ \text { Air } & 3 \\ \text { Air } & 10 \\ - & 2 \\ \text { Air } & 10 \\ \text { Air } & 5\end{array}$

-
5,10
-
5

3
5
5
2
5
10

10
5

$5 \mathrm{~mL} / \mathrm{h}$
3
5
3
10
2
10
5

800
1400
1400
900

800
1200
800
900

$550-1200$
800

900
1000

$1000^{\circ} \mathrm{C}$.
800
1000
900
1000
1000
600
1500

2
1

1
1
-
1
2
1
1
1
1
1
0.5
1

1
1
1
0.5
1
1
1
1

\section{Cig}

CNFs@50\% lignin=143 nm at

$900^{\circ} \mathrm{C}$. CNFs@50\%

lignin $=0.124 \mathrm{~nm}$ at $1100^{\circ} \mathrm{C}$

$\mathrm{N}_{2} \quad \sim 140-100 \mathrm{~nm} @ 800-1400^{\circ} \mathrm{C}$

1) Inert 2) $\mathrm{CO}_{2} \quad$ 1) carbonized $\left.=567 \mathrm{~nm} 2\right)$

1) carbonized $=567 \mathrm{~nm} 2)$

$5 \% \mathrm{H}_{2}$ in $\mathrm{N}_{2} \quad$ Range from 163 to $201 \mathrm{~nm}$

Ar $\sim 200 \mathrm{~nm}$

Inert gas $\quad 370 \mathrm{~nm}$

$\mathrm{N}_{2} \quad$ Less than $100 \mathrm{~nm}$

Ar -
$\mathrm{N}_{2} \quad 20,40$, and $50 \mathrm{wt} \%$ lignin is
$0.44,0.41$, and $0.3 \mu \mathrm{m}$

$\mathrm{N}_{2} \quad-$

$\mathrm{N}_{2} \quad$ PAN/Lignin (nm), 100/0

$\sim 291.48,90 / 10 \sim 184.22$,

80/20 122.45, 70/30 79.35

$\mathrm{N}_{2}$
$\mathrm{~N}_{2}$
$\mathrm{~N}_{2}$
$\mathrm{~N}_{2}$
$\mathrm{~N}_{2}$
$\mathrm{~N}_{2}$
$\mathrm{~N}_{2}$
$\mathrm{Ar}$

$124-192 \mathrm{~nm}$

$1007 \pm 670 \mathrm{~nm}$

$650 \mathrm{~nm}$

$300 \mathrm{~nm}$

$1 \mu \mathrm{m} .700-900 \mathrm{~nm}$ in $\mathrm{Fe}_{3} \mathrm{O}_{4}$

CNTs 347-370 nm

Dalton et al., 2019

Meng et al., 2019

Dai et al., 2019

Wei J. et al., 2019

Schlee et al., 2019b

Schlee et al., 2019a

CNFs-800 $=253 \pm 11$

CNFs-1000 $=236 \pm 18$

CNFs-1200 $=225 \pm 22$

CNFs-1500 $=200 \pm 20$ 
TABLE 2 | Continued

\begin{tabular}{|c|c|c|c|c|c|c|c|c|c|}
\hline \multicolumn{4}{|c|}{ Thermostabilization } & \multicolumn{4}{|c|}{ Carbonization } & \multirow{2}{*}{$\begin{array}{l}\text { Diameter (d) of carbonized } \\
\text { fibers }\end{array}$} & \multirow[t]{2}{*}{ References } \\
\hline Heating rate $\left({ }^{\circ} \mathrm{C} / \mathrm{min}\right)$ & $\begin{array}{l}\text { Max. } \\
\text { Temp. } \\
\left({ }^{\circ} \mathrm{C}\right)\end{array}$ & $\begin{array}{l}\text { Residence } \\
\text { time at } \\
\max . \mathrm{T}(\mathrm{h})\end{array}$ & Purge gas & $\begin{array}{l}\text { Heating } \\
\text { rate } \\
\left({ }^{\circ} \mathrm{C} / \mathrm{min}\right)\end{array}$ & $\begin{array}{c}\text { Max. } \\
\text { Temperature } \\
\left({ }^{\circ} \mathrm{C}\right)\end{array}$ & $\begin{array}{c}\text { Residence } \\
\text { time at } \\
\max . T(h)\end{array}$ & Purge gas & & \\
\hline 0.51 & $\begin{array}{l}220 \\
280\end{array}$ & 86 & Air & 5 & 1200 & 1 & $\operatorname{Ar}$ & - & Beck et al., 2017 \\
\hline $0.5,1,1.5$ & 250 & 1 & Air & 5 & 900 & 1 & $\operatorname{Ar}$ & - & Aslanzadeh et al., 2017 \\
\hline 1 & 280 & 1 & aerobic & 5 & 1000 & - & $\mathrm{N}_{2}$ & $\begin{array}{l}\mathrm{NiCO}_{2} \mathrm{O}_{4} @ \mathrm{CNF} 82 \sim 875 \text { nm } \\
\mathrm{NiCO}_{2} \mathrm{O}_{4} @ \mathrm{CNF} 55 \sim 1830 \mathrm{~nm}\end{array}$ & Lei et al., 2017 \\
\hline 0.5 & 220 & 6 & Air & 5 & 900 & 1 & Ar & - & Fang et al., 2017b \\
\hline- & 250 & 3 & Air & - & 1200 & 1 & $\mathrm{~N}_{2}$ & $150 \mathrm{~nm}$. & Shi et al., 2017 \\
\hline $0.08,0.8$ & 200 & 100,1 & Air & 10 & 900 & - & $\mathrm{N}_{2}$ & $\begin{array}{l}600 \mathrm{~nm}^{-1} \mu \mathrm{m} \text { for } \mathrm{CFs}, \\
600 \mathrm{~nm}^{-3} \mu \mathrm{m} \text { for } \mathrm{CFs}+\mathrm{H}_{3} \mathrm{PO}_{4}\end{array}$ & $\begin{array}{l}\text { García-Mateos et al., } \\
2017\end{array}$ \\
\hline- & 250 & 1 & Air & & 1300 & - & $\mathrm{N}_{2}$ & 200-500 smooth fibrous & Jin et al., 2014 \\
\hline 0.25 & 200 & 24 & Air & 10 & 900 & - & $\mathrm{N}_{2}$ & $200 \mathrm{~nm}$ smooth fibers & Lallave et al., 2007 \\
\hline 0.05 & 200 & 36 & Air & 10 & 1000 & - & $\mathrm{N}_{2}$ & - & $\begin{array}{l}\text { Ruiz-Rosas et al., } \\
\text { 2010b; Berenguer } \\
\text { et al., } 2015\end{array}$ \\
\hline \multicolumn{3}{|c|}{ Cured by E-beam irradiation } & $\mathrm{N}_{2}$ & 10 & 1000 & 1 & $\mathrm{~N}_{2}$ & - & Seo et al., 2011 \\
\hline 1 & 250 & 3 & Air & 10 & 1000 & 1 & $\mathrm{~N}_{2}$ & Half of the precursor fibers & Choi et al., 2013 \\
\hline 1 & 200 & 2 & Air & 10 & 900 & 2 & $\mathrm{~N}_{2}$ & $\sim 500 \mathrm{~nm}$ & Wang et al., 2013 \\
\hline 5 & 250 & 1 & Air & $\begin{array}{c}\text { 1)* } 18.72) \\
10\end{array}$ & 1000 & 5 and 1 & $\mathrm{~N}_{2}$ & $\begin{array}{l}\sim 639 \mathrm{~nm} \text { with } 0 \% \mathrm{MWNTs} \\
\sim 579-816 \mathrm{~nm} \text { with MWNTs }\end{array}$ & Teng et al., 2013 \\
\hline- & - & - & - & 1) 10 2) 10 & 1000 & 1 and 2 & 1) $M i x^{a}$ 2) $\mathrm{Ar}$ & $\begin{array}{l}\text { Outer } d=476 \mathrm{~nm} \text {, Inner } \\
d=330 \mathrm{~nm} \text {, Core-shell }=3.5 \\
\mu \mathrm{m}\end{array}$ & Xu et al., 2013 \\
\hline- & - & - & - & 10 & 1000 & $\begin{array}{c}2 \text { then } 20 \\
\min \end{array}$ & 1) $M i x^{a}$ 2) $\left.\operatorname{Ar} 3\right) M i x^{b}$ & - & Xu et al., 2014 \\
\hline \multicolumn{4}{|c|}{ Simultaneous thermostabilization and carbonization } & 1) 10 2) 10 & 600 or 850 & 0.5 & $\mathrm{~N}_{2}$ & $\begin{array}{l}\text { With } \mathrm{NaOH}=300-500 \mathrm{~nm} \text { with } \\
\mathrm{KOH}=100-300 \mathrm{~nm}\end{array}$ & $\begin{array}{l}\text { Hu and Hsieh, 2013; } \\
\text { Hu et al., } 2014\end{array}$ \\
\hline Range $0.5,1,10$ & 220 & 8 & Air & 5 & 1200 & 1 & $\operatorname{Ar}$ & $\begin{array}{l}\text { Neat PVA: } \sim 210 \mathrm{~nm} \\
\text { Lignin/PVA: 100-150 nm }\end{array}$ & Lai et al., 2014b \\
\hline 5 & 250 & 1 & Air & - & 900 & 1 & Ar & - & Hishida et al., 2009 \\
\hline 2 & 300 & 2 & Air & 2 & 1200 & 1 & $\mathrm{~N}_{2}$ & $\sim 250 \mathrm{~nm}$ & Schreiber et al., 2015 \\
\hline 5 & 250 & 1 & Air & 1) 20 2) 10 & 1000 & 1 & $\mathrm{~N}_{2}$ & $634 \pm 87 \mathrm{~nm}$ & Dallmeyer et al., 2014 \\
\hline- & 250 & 2 & - & - & 800 & 2 & $\mathrm{Ar}$ & $800 \mathrm{~nm}$ to $1.2 \mu \mathrm{m}$ & Salas et al., 2014 \\
\hline 10 & 250 & 2 & Air & 10 & 1400 & 0.5 & $\mathrm{~N}_{2}$ & $\sim 561.7-739.6 \mathrm{~nm}$ & Youe et al., 2015 \\
\hline
\end{tabular}

*Numbers in a single cell show a multi-step process was performed. ${ }^{a} 500 \mathrm{~mL} / \mathrm{min}$ hydrogen $\left(\mathrm{H}_{2}\right)$ and $1 \mathrm{~mL} / \mathrm{min}$ argon (Ar). ${ }^{b}$ Acetylene/argon mixture (100:300 $\left.\mathrm{mL} / \mathrm{min}\right)$. 

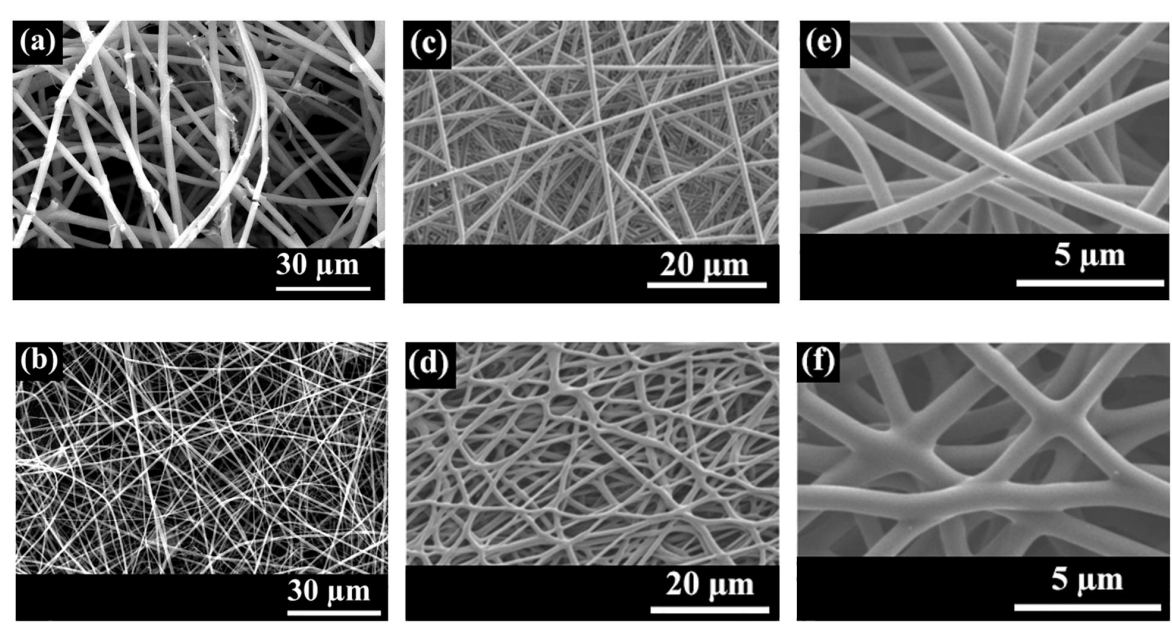

FIGURE 4 | SEM images of softwood kraft lignin electrospun fibers and carbonized fibers. (a) fibers from aqueous NaOH solutions of 7\% (lignin/PEO: 95/5) (PEO, $M_{v}=5 \times 10^{6} \mathrm{~g} / \mathrm{mol}$ ), (b) fibers from solution of $11 \%$ (lignin/PEO: 95/5) (PEO, Mv $=5 \times 10^{6} \mathrm{~g} / \mathrm{mol}$ ) in DMF, (c) thermostabilized non-bonded fibers from high molecular weight fraction of lignin and PEO ( $\left.M_{V}=1 \times 10^{6} \mathrm{~g} / \mathrm{mol}\right)$, (d) thermostabilized bonded fibers from a 70/30 wt\% blend of high and low molecular weight fraction of lignin and PEO $\left(\mathrm{M}_{\mathrm{v}}=1 \times 10^{6} \mathrm{~g} / \mathrm{mol}\right)$, (thermostabilization at $250^{\circ} \mathrm{C}$ and a heating rate of $\left.5^{\circ} \mathrm{C} / \mathrm{min}\right)$, (e,f) carbonized fibers of $(\mathbf{c}, \mathbf{d})$ at $1000^{\circ} \mathrm{C}$. (a,b) Poursorkhabi et al. (2015) (License CC BY-NC-ND, John Wiley and Sons). (c-f) Reprinted with permission (Dallmeyer et al., 2014) (License Number 4806541107321), WILEY-VCH Verlag GmbH \& Co. KGaA, Weinheim.

fiber with superior mechanical properties and lower weight (Köhler et al., 2017).

The activation of carbon fiber (porous carbon fiber) enhanced the fabrication in different forms and facilitated robust fiber formation. Activated carbon fibers were produced by carbonization of alkaline solutions of $\mathrm{PEO} /$ lignin electrospun fibers at $850^{\circ} \mathrm{C}$ which significantly decreased the impregnation ratio ( $\mathrm{Hu}$ and Hsieh, 2013). The existence of alkali elements enhanced the shape retention and fiber thermal stability demonstrating that the fibers could be thermostabilized and carbonized in one step under a nitrogen atmosphere.

Multi-walled carbon nanotubes (MWNTs) (Teng et al., 2013) and metal particles such as Platinum (Pt), (Ruiz-Rosas et al., 2010b; Gao et al., 2015). Palladium (Pd) and Gold (Au) (Gao et al., 2015) were also added to the fibers, and their effect on the characteristics of carbonized fibers was investigated. Incorporation of the nanoparticles to lignin carbon fibers improved the mechanical properties, crystallinity of the material and provided further functionality (active phase) as well as value to the material (Beisl et al., 2017; García-Mateos et al., 2019).

\section{CHARACTERIZATION OF THE CARBONIZED FIBERS}

\section{Electron Microscopy}

Scanning electron microscopy (SEM) is the best technique to evaluate the performance and diameter of fibers. SEM allows one to understand the quality of fibers by characterizing smoothness, roughness or porosity of a fiber surface along with discerning if the surface is non-uniform, beaded, or interconnected (Tagawa and Miyata, 1997; Tanaka et al., 1999; Dallmeyer et al., 2010). Prior to imaging, the electrospun lignin fiber was sputter coated with gold for 10-20 s and examined using accelerating voltages of $5-20 \mathrm{kV}$. The lignin-carbon fibers formed had a diameter of $80-$ $30 \mu \mathrm{m}$. The challenge in decreasing the diameter is restricted by the preparing conditions, for example, clogging melt extrusion die (Kadla et al., 2002; Kadla and Kubo, 2004; Kubo and Kadla, 2004, 2005).

Electrospinning can produce lignin fibers ranging in size from sub-micron to a few micrometers in diameter. The diameter of the lignin fibers depends on multiple variables including type of lignin, solvent, binder polymer; viscosity, concentration, conductivity, surface tension, electrospinning voltage, feed and rate, and the nozzle to collector distance (Huang et al., 2003; Ramakrishna et al., 2005; Dallmeyer et al., 2010). A relatively broad range of diameters has been reported in the literature (Dallmeyer et al., 2010; Teng et al., 2013) and are shown in Figure 4.

Figure 4 compares the SEM images of electrospun softwood kraft lignin (MeadWestvaco Indulin-AT, United States) fibers and carbonized fibers. Figures $\mathbf{4 a} \mathbf{a} \mathbf{b}$ shows electrospun blend lignin/PEO fibers from aqueous $\mathrm{NaOH}$ and DMF solutions, respectively. Figures $\mathbf{4 c}-\mathbf{f}$ demonstrates electrospun fibers from PEO and fractionated lignin and their carbonized fibers. It was observed that enhancing the low-molecular-weight content of lignin increased the chance of fusion of fibers together.

Transmission electron microscopy (TEM) is used to study the fibers surface, strength-structure relationship of the carbon fiber, and dispersion of additives such as metal particles (RuizRosas et al., 2010b; Lai et al., 2014a) or carbon nanotubes (Teng et al., 2013) in the carbonized fibers. This method is also used to study the carbon structure of the fibers (Hu and Hsieh, 2013; Lai et al., 2014b). The TEM of carbonized samples (powder) were dispersed in ethanol or distilled water by ultrasonic treatment then a droplet was placed on a copper grid supports which was 
A

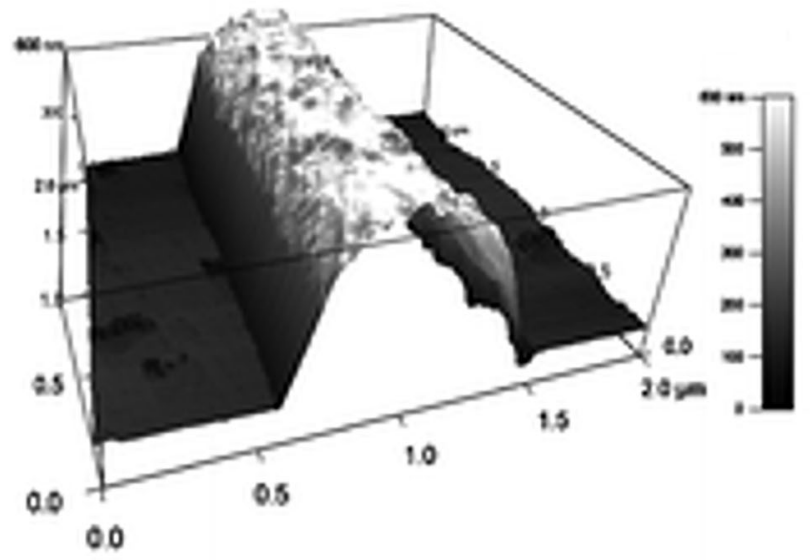

B

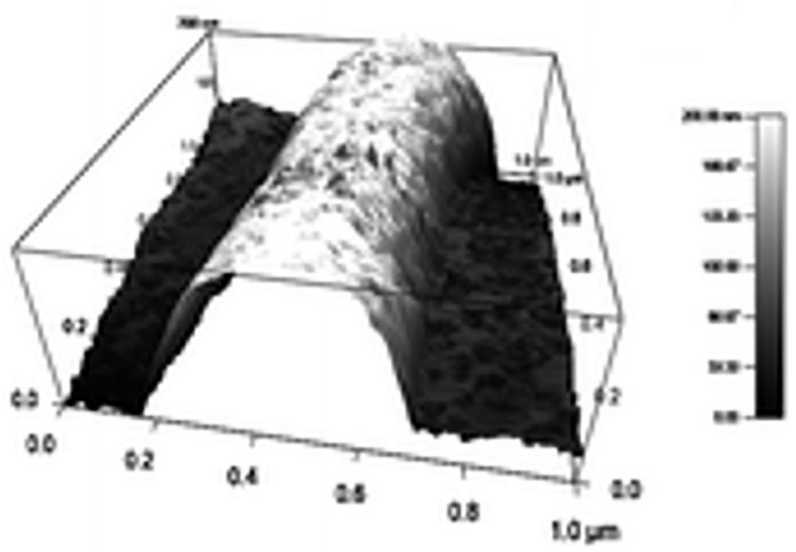

FIGURE 5 | AFM images of activated carbon fibers from blend fibers of (alkali lignin/PEO: 9/1) activated with (A) NaOH, and (B) $\mathrm{KOH}$. The fibers were carbonized at $850^{\circ} \mathrm{C}$ for $0.5 \mathrm{~h}$ in nitrogen. Reproduced from Hu and Hsieh (2013) with permission from The Royal Society of Chemistry (Order license ID 1029915-1).

then examined by a field emission TEM at an accelerating voltage of $\sim 100-200 \mathrm{kV}$. Electrospinning of PAN-lignin fibers displayed a homogeneous circular cross-section with $300 \mathrm{~nm}$ diameter at a concentration of $50 \mathrm{wt} . \%$ lignin. At $60 \mathrm{wt}$ \% lignin, the formation of beaded fibers occurred and at $80 \mathrm{wt} \%$, electrospraying had taken place (Seo et al., 2011).

Ruiz-Rosas et al. (2010b) obtained Alcell lignin composite fibers with platinum by co-electrospinning. The fiber diameters were between $\sim 800 \mathrm{~nm}$ and $3 \mu \mathrm{m}$. Thermostabilized fibers were not fused and diameters remained in the same range. The maximum deterioration in diameter was between $400 \mathrm{~nm}$ and $1 \mu \mathrm{m}$ after carbonization at the highest temperatures. TEM displayed a smooth surface of the fiber with $\mathrm{Pt}$ dispersion of $10.5 \%$.

Hollow carbon fibers have been produced from co-electrospun fibers. In the co-electrospinning process a tri-axial configuration was used. In this configuration, ethanol, lignin solution, and glycerin solution were the outer layer, middle layer, and the inner layer, respectively (Lallave et al., 2007). The fiber was between $400 \mathrm{~nm}$ and $2 \mu \mathrm{m}$ and reduced to $200 \mathrm{~nm}$ after carbonization due to the removal of non-carbon compounds, i.e., Oxygen, Hydrogen and Sulfur elements for kraft lignin (Lai et al., 2014b).

\section{Atomic Force Microscopy (AFM)}

AFM is used to study the roughness and porosity of the surface of carbon fibers (Hu and Hsieh, 2013). The images obtained from the AFM depends on the shape, size and functionality of the probe tips (Furuno et al., 1998). AFM has different assortment for imaging such as height (smoothness of surface), phase images (sample viscosity and hardness) and amplitude (vibrating the probe) depending on the working environments. The electrospun and carbonized fiber was prepared by fixing the fibers on the surface of cleaved mica and the tip scans over the surface by continuous tapping. Figure 5 shows AFM images of carbonized (alkali lignin/PEO: 9/1 wt/wt) fibers (Hu and Hsieh, 2013). The fibers were produced from aqueous solutions of $\mathrm{NaOH}$ or $\mathrm{KOH}$ and carbonized at $850^{\circ} \mathrm{C}$ for 30 min under a nitrogen blanket. Both images in Figure 5 demonstrate a porous fiber surface.

\section{Elemental Analysis}

$\mathrm{CHNS} / \mathrm{O}$ analysis is used to measure the degree of carbonization and the percentage of elements in thermally treated lignin fibers (Lallave et al., 2007). The existence of C-O groups has an influence on the solid electrolyte interphase layer forming in the reaction (Choi et al., 2013). Lallave et al. (2007) characterized the percentage of elements in the lignin fibers and thermally treated fibers by elemental analysis. The authors found that thermostabilized fibers have a higher oxygen percentage depending on the temperature and heating rate. Fibers carbonized at $900^{\circ} \mathrm{C}$, and above have a carbon content of more than $\sim 90 \%$.

\section{X-Ray Photoelectron Spectroscopy (XPS and EDX)}

XPS and EDX is used as an alternative method for elemental analysis of the fibers (Ruiz-Rosas et al., 2010b; Hu and Hsieh, 2013; Wang et al., 2013). This method was used to investigate the surface chemistry of the samples (Ruiz-Rosas et al., 2010b; Wang et al., 2013).

The surface concentration of oxygen in carbonized fiber (carboxyl, carbonyl, ester, and anhydride groups) increased and the percentage of hydrogen decreased after thermostabilization (in the form $\mathrm{CO}$ or $\mathrm{CO}_{2}$ ) which resulted in an increase in the $T_{g}$ of the material (Lallave et al., 2007; Ruiz-Rosas et al., 2010b).

Wang et al. (2013) analyzed the percentage of carbon, nitrogen and oxygen of the carbonized lignin fibers by XPS. The carbonized (lignin/PEO: 90/10) fibers at a $900^{\circ} \mathrm{C}$ had $89.11 \%$ carbon and $10.89 \%$ oxygen. The $N$-doped fibers were produced by the second heating of urea impregnated carbon fibers to the $900^{\circ} \mathrm{C}$. These fibers had a $76.85 \%$ carbon, $9.94 \%$ oxygen, and $13.21 \%$ nitrogen. 


\section{Fourier Transform Infrared Spectroscopy (FTIR)}

FTIR is used to detect changes in chemical functionalities after thermostabilization (Hu and Hsieh, 2013; Cho et al., 2019b). It is also used to confirm the complete removal of chemical groups other than carbon in the carbonized fibers (Choi et al., 2013).

Choi et al. (2013) reported producing carbon fibers from lignin/PAN blend fibers. FTIR of the carbonized fibers made from blends of lignin/PAN showed peaks at around $1000 \mathrm{~cm}^{-1}$ indicating the presence of $\mathrm{C}-\mathrm{O}$ groups while the fibers produced only from PAN did not show any significant peak, presenting complete carbonization.

\section{Thermal Analysis}

The thermal stability of the electrospun fibers and carbonized fibers up to $1000^{\circ} \mathrm{C}$ was investigated by thermogravimetric analysis (TGA) in both an air and nitrogen atmosphere (RuizRosas et al., 2010b; Seo et al., 2011). Non-isothermal oxidation profiles of thermo-stabilized lignin fibers displayed an important oxidation rate at $250^{\circ} \mathrm{C}$. Resistance to oxidation of carbonized fibers will be enhanced at higher carbonization temperatures. Lack of superficial defects, as well as ordered carbon, were presented as the causes for higher oxidation onset temperatures (Ruiz-Rosas et al., 2010b). TGA examination of fibers in $N_{2}$ atmosphere is used to calculate the carbonization yield as an alternative of direct weight measurements (Lallave et al., 2007; Seo et al., 2011).

Differential scanning calorimetry (DSC) studies are used to determine the transition points of the fibers. DSC results for Lignin/PEO fibers showed the disappearance of the melting point of PEO (Hu and Hsieh, 2013). It is due to a good spreading of $\mathrm{PEO}$ in the reinforcing agent (lignin), higher chain entanglement between the two polymers, and the inability of the PEO to crystalize. The other application of DSC is detecting the softening point of the fiber after thermostabilization.

\section{Raman Spectroscopy}

Ramen spectroscopy has been used to study the carbon structure of fibers. Raman spectrum of carbonized lignin fibers are displayed as two broad overlapping peaks resulting from disordered carbon with semi-structural organization. The first peak ( $D$ band) at $\sim 1300 \mathrm{~cm}^{-1}$ is assigned to carbon hybridization $\left(\mathrm{sp}^{3}\right)$ in polycrystalline graphite. It represents the disordered structure, which is called "turbostratic carbon structure" and can constitute the imperfections in the graphitized structure. Another peak ( $\mathrm{G}$ band) at $\sim 1576 \mathrm{~cm}^{-1}$ because of carbon hybridization $\left(\mathrm{sp}^{2}\right)$ as well as stretching mode in the graphite plane (Ferrari and Robertson, 2000). Usually, deconvolution of the Raman spectra peaks are used to measure the intensity and position of each band. The deconvolution of the spectra to two (Choi et al., 2013; Teng et al., 2013; Dallmeyer et al., 2014; Youe et al., 2015), three (Jawhari et al., 1995), or four peaks (Ruiz-Rosas et al., 2010b; Hu et al., 2014; Berenguer et al., 2015) has been reported in the literature. After deconvolution of the spectrum to 4 peaks, two smaller bands at $\sim 1515$ and $1170 \mathrm{~cm}^{-1}$ appear. These bands are attributed to impurities such as ions or oxygen superficial groups (Ruiz-Rosas et al., 2010b).

The ratio of intensities of $D$ to $G$ band $\left(R=I_{D} / I_{G}\right)$ is used to study the extent of the ordered graphitic structure. Increasing the $R$-value reveals the enhance in the disordered structure and decreased size of graphite sheets. Crystallite size of graphite $\left(\mathrm{L}_{\alpha}\right)$ $(\mathrm{nm})$ and graphitic mole fraction $\left(\mathrm{x}_{\mathrm{G}}\right)$, can be calculated from Eqs (1) and (2) (Cançado et al., 2006):

$$
L_{\alpha}=\left(2.4 \times 10^{-10}\right) \lambda^{4}\left(\frac{I_{D}}{I_{G}}\right)^{-1}
$$

Where $\lambda$ is the incident laser wavelength (nm).

$$
x_{G}=\frac{\mathrm{I}_{\mathrm{G}}}{\mathrm{I}_{\mathrm{D}}+\mathrm{I}_{\mathrm{G}}}=\frac{1}{1+\mathrm{R}}
$$

Vicinity of the center of deconvoluted $\mathrm{G}$ band to the value for graphite $\left(1582 \mathrm{~cm}^{-1}\right)$ was attributed to the onset of the structural organization although there were still some disordered carbon present (Lallave et al., 2007).

The effects of carbonization temperature were studied with Raman spectroscopy between 600 and $1400^{\circ} \mathrm{C}$ to calculate the degree of graphitization (Ruiz-Rosas et al., 2010b; Dallmeyer et al., 2014; Liu H.C. et al., 2015; Schreiber et al., 2015; Youe et al., 2015). The results showed that at higher temperatures a narrower $\mathrm{G}$ and $\mathrm{D}$ band occurred and enhanced the intensity of the $\mathrm{G}$ band signal. Increasing the carbonization temperature leads to a decrease in the contribution of the disordered structure of carbonized fibers (Rodríguez-Mirasol et al., 1996; Ruiz-Rosas et al., 2010b). Disordered structure of carbonized fibers which had dispersed metal particles such as platinum or nitrogen-doped fibers increased due to the steric hindrance effect of particles or nitrogen induced defects (Keskar et al., 2005; Ruiz-Rosas et al., 2010b; Wang et al., 2013). Structure of carbonized lignin fibers blended with a crystalline polymer such as cellulose acetate or PVA became more disordered by increasing the content of lignin which has a more amorphous structure (Choi et al., 2013; Lai et al., 2014b; Schreiber et al., 2015).

\section{X-Ray Diffraction (XRD)}

The peaks of lignin/PAN fibers at $2 \theta$ of $28.8^{\circ}$ and $16.8^{\circ}$ are due to (110) and (100) crystallographic planes of PAN. These peak intensities decrease after thermostabilization due to variation in the structure of PAN (Seo et al., 2011).

The carbonized lignin shows a broad diffraction peak centered at $2 \theta \approx 25-26^{\circ}$ which is due to (002) crystallographic planes of graphite crystallites (Seo et al., 2011; Teng et al., 2013). For some samples, peaks were detected at around $63.3^{\circ}$ and $50.4^{\circ}$ assigned to (004) and (100) planes in graphitic structure. The interplanar spacing, $d_{002}$, of the carbonized fibers improved by increasing the lignin content and reduction of density. Thus, higher lignin content in fiber will lead to the formation of higher porous carbon structures (Lai et al., 2014b). All the lignin-based carbon fibers had a broadband from 15 to $33^{\circ}$ due to an amorphous carbon structure. 


\section{Surface Area Analysis}

Porosity and surface area of the fibers were calculated by $\mathrm{N}_{2}$ adsorption-desorption at $-196^{\circ} \mathrm{C}$ and application of Brunauer, Emmett, and Teller (BET) equation (Lallave et al., 2007; RuizRosas et al., 2010b; Wang et al., 2013).

The porosity of the lignin fibers increased during the carbonization process by the removal of volatile material. It was observed that the surface area of carbonized lignin improved from 524 to $1195 \mathrm{~m}^{2} / \mathrm{g}$ by increasing the temperature from 600 to $900^{\circ} \mathrm{C}$. After a certain temperature, further increasing the temperature to $\left(1000^{\circ} \mathrm{C}\right)$ had the opposite effect. It destroyed the porous structure and reduced the surface area $\left(821 \mathrm{~m}^{2} / \mathrm{g}\right)$ due to reorganization of the solid at $1000^{\circ} \mathrm{C}$ (Ruiz-Rosas et al., 2010b).

Wang et al. (2013) showed a decrease in the surface area from 473 to $381 \mathrm{~m}^{2} \cdot \mathrm{g}^{-1}$ of lignin-carbonized fibers doped with nitrogen which resulted in the formation of meso/macroporous structure.

The pore volume of lignin-carbonized fibers enhanced by increasing the temperature due to the activation by oxygen (activating agent) during carbonization (Ruiz-Rosas et al., 2010b).

The surface area of PAN/lignin-carbonized fibers reduced from 12.9 to $6.3 \mathrm{~m}^{2} . \mathrm{g}^{-1}$ with increasing content of lignin, in spite of reduction in diameter due to fiber fusion in the network of the fiber (Choi et al., 2013).

Addition of alkali metal hydroxides such as $\mathrm{NaOH}$ or $\mathrm{KOH}$ to the lignin solutions traps these materials inside the fibers. Activated carbon fibers were produced from carbonized lignin fibers containing alkali metal compounds (Hu and Hsieh, 2013).

The carbonized lignin-based fibers showed different types of isotherms for porous materials such as types I, II, or IV depending on the fiber composition and carbonization conditions (RuizRosas et al., 2010b; Hu and Hsieh, 2013; Wang et al., 2013; Lai et al., 2014b). Reversible adsorption was monitored by comparing the desorption and adsorption curves (Ruiz-Rosas et al., 2010b).

\section{Mechanical Properties}

Achieving high modulus and strength, lignin carbon fibers require highly oriented anisotropic-graphitic structures along the fiber axis (Davé et al., 1993). Thus, the polymer chains have to be oriented and aligned in one direction before fiber solidification. Fiber diameter also affects the strength. Fibers with a smaller diameter will have less defects and will be molecularly oriented along the fiber axis (Tagawa and Miyata, 1997; Tanaka et al., 1999; Dallmeyer et al., 2010).

Lignin is an amorphous aromatic biopolymer that has a $3 \mathrm{D}$ structure. Because of this, molecular orientation is the key to high mechanical properties (modulus and strength) which is limited (Davé et al., 1993). The mechanical characterization of ligninbased carbon fibers were tested using tensile testing machines according to ASTM D638 (Seo et al., 2011; Teng et al., 2013).

Seo et al. (2011) displayed the enhancement of tensile strength of PAN-lignin (50/50) fiber from around $\sim 100$ to more than $800 \mathrm{MPa}$ (around 480\%) for fiber irradiated by $2000 \mathrm{KGy}$ dosage compared to PAN-lignin fiber non-irradiated. This is due to stabilization of PAN during irradiation.
Teng et al. (2013) measured the tensile strength of MWNTs dispersed in PEO-lignin carbonized fiber using a micro-tensile tester instrument at rate of $0.02 \mathrm{~cm} \mathrm{~s}^{-1}$. The tensile strength reduced by inclusion of $1 \mathrm{wt} . \%$ MWNTs but stayed equivalent by increasing the concentration. Moreover, the tensile strength decreased by increasing the diameters of the fiber. The strength of PEO-lignin fibers without MWNTs increased from 5.13 to $45.03 \mathrm{MPa}$ after carbonization. The inclusion of $4 \mathrm{wt} . \%$ MWNTs decreased the strength to $2.46 \mathrm{MPa}$ due to the poor dispersion. The modulus of PEO-lignin fibers enhanced from 5.1 to $6.2 \mathrm{GPa}$ for carbonized fibers. Incorporation of MWNTs enhanced the modulus but reduced after carbonization from 6.2 to $2.4 \mathrm{GPa}$ due to the change in the morphology of the fibers. The percentage of elongation and toughness reduced after incorporation of MWNTs but the percentage of elongation enhanced after carbonization with no effect on toughness. For carbon fibers, no enhancement was observed by inclusion of MWNTs. It is opposite than the trend observed for PAN, in which addition of MWNTs improved the fiber strength due to the random order of MWNTs in carbon fibers and poor adhesion and dispersion lead to decreasing in the mechanical characteristics.

\section{APPLICATION OF THE CARBONIZED FIBERS}

In recent years, the production of carbon fiber from by-product lignin is a key material directly linked to automotive industry, construction aerospace and energy industry (Liu W.-J. et al., 2015; Kai et al., 2016). Energy manufacturing is the fast-growing industry for renewable resource-based alternatives to traditional petroleum-based materials. In particular, supercapacitors, energy storage and dye-synthesized solar cells (DSSCs) are increasingly in demand as the solution to providing low-cost, light-weight, and more energy-efficient devices (Fang et al., 2017a).

Polyacrylonitrile (PAN) is an important precursor material for the production of carbon fiber. However, PAN has a nonrenewability and intensive processing conditions as well as a high cost which adds to the product's final cost limiting the application for anode production in batteries (Choi et al., 2013; Wang et al., 2013). Besides lignin, several types of materials have been tested as a potential source of biomass-based carbon such as rice straw (Zhang et al., 2009), bacterial cellulose (Wang et al., 2015), egg protein (Li et al., 2013), sugar (Xing et al., 1996), olive, cherry stones (Caballero et al., 2011), and peanut shells (Fey et al., 2003), etc. However, the disadvantage of these resources is complicated processing (Wang et al., 2013).

Graphene and non-graphene carbons were applied as a major component to produce the electrode for lithium-ion battery anodes (LIBs). This has resulted from their porous structure, processability, availability, chemical stability and low cost (Wang et al., 2013). One of the most important factors for the anode material is to have a high rate capability and high capacity (Choi et al., 2013).

The structural and chemical stability of these materials through Li-ion insertion/de-insertion is the essential property that allows for a reversible charge/discharge process 
TABLE 3 | Electrochemical properties of carbonized fibers as lithium-ion battery anodes.

\begin{tabular}{|c|c|c|c|c|c|c|}
\hline $\begin{array}{l}\text { Precursor fiber material used for } \\
\text { electrode }\end{array}$ & $\begin{array}{l}\text { Charge/ } \\
\text { discharge } \\
\text { cycles }\end{array}$ & $\begin{array}{c}\text { Current } \\
\text { density } \\
\left(\mathrm{mA} \cdot \mathrm{g}^{--1}\right)\end{array}$ & $\begin{array}{l}\text { Initial charge } \\
\text { capacity } \\
\left.\text { (mA.h.g }{ }^{-1}\right)\end{array}$ & $\begin{array}{c}\text { Initial discharge } \\
\text { capacity } \\
\left(\mathrm{mA} \cdot \mathrm{h} \cdot \mathrm{g}^{-1}\right)\end{array}$ & $\begin{array}{c}\text { Initial } \\
\text { columbic } \\
\text { efficiency }(\%)\end{array}$ & References \\
\hline Lignin/PAN: 50/50, 30/70, 0/100 & 50 & 37.2 & $300-310$ & - & - & Choi et al., 2013 \\
\hline $\begin{array}{l}\text { Lignin/PEO: } 97 / 3 \text { Non-interconnected } \\
\text { fibers }\end{array}$ & 50 & 30 & 365 & $\sim 650$ & 56.2 & Wang et al., 2013 \\
\hline Lignin/PEO: 90/10 Interconnected fibers & 50 & 30 & 445 & $\sim 650$ & 68.2 & $\begin{array}{l}\text { Hishida et al., 2009; } \\
\text { Wang et al., } 2013\end{array}$ \\
\hline $\begin{array}{l}\text { Lignin/PEO: 90/10 Interconnected fibers } \\
\text { N-doped }\end{array}$ & 50 & 30 & 576 & $\sim 650$ & 82.8 & Wang et al., 2013 \\
\hline Carbonized nanofibers Lignin/PAN: 50/50 & 400 & 20 & 471.0 & 304.4 & 64.6 & Shi et al., 2017 \\
\hline $\begin{array}{l}\text { Mesoporous carbonized nanofibers } \\
\text { Lignin/PAN: } 50 / 50\end{array}$ & 400 & 20 & 618.4 & 384.4 & 62.2 & Shi et al., 2017 \\
\hline Lignin/Cellulose acetate & 200 & 50 & 290 & 555 & 52 & Jia et al., 2018 \\
\hline PLA or TPU/Lignin 50/50; 70/30 & 500 & 372 & 611 & 572 & - & Culebras et al., 2019 \\
\hline Lignin/PVA with 35 wt $\% \mathrm{Fe}_{2} \mathrm{O}_{3}$ & 80 & $50,100,200$ & - & $\sim 715$ & - & Ma et al., 2019 \\
\hline PAN & Second & $10,30,100$ & $\sim 450$ & - & - & Kim et al., 2006 \\
\hline Graphite & second & $10,30,100$ & $\sim 320$ & - & - & Kim et al., 2006 \\
\hline
\end{tabular}

(Choi et al., 2013). Limited theoretical capacity (372 mA.h.g ${ }^{-1}$ ) and long charging times are limitations of commercial graphite anodes (Choi et al., 2013).

Nano-carbon materials that enhance the rate capability of anodes have high electrical conductivity and large specific surface area (Choi et al., 2013; Wang et al., 2013). Examples of these nano-carbon materials are carbon nanofibers, carbon nanotubes, and graphene. Smaller carbon fiber diameters will lead to higher surface areas as well as better rate capability. Choi et al. (2013) showed that the carbon nanofibers diffusion length of Li-ion is shorter than micro-size graphite materials.

The electrochemical properties of carbonized fibers as lithiumion battery anodes are summarized in Table 3. For fabricating electrodes, carbon nanofibers are blended with other materials as shown in Table 3. Choi et al. (2013) made electrodes from lignin carbon nanofibers. They obtained an electrode loading level around $1-2 \mathrm{mg} / \mathrm{cm}^{2}$ using lithium metal as anode and a polypropylene separator. The fibers from blended lignin/PAN precursors had a smaller surface area. However, the plateau was longer for these fibers due to oxygen groups on the fiber surface. Their results showed that the carbon fibers from lignin/PAN (30/70 and 50/50 wt.\%) had a similar rate capability except for initial irreversible capacity. The fibers showed a cycle performance and a high rate compared to traditional PAN fibers.

Wang et al. (2013) fabricated Li-ion batteries by using a carbon fiber mat and a lithium foil as the anode and counter electrode, respectively, made from lignin with different percentages of PEO. The electrical conductivity of interconnected fiber mats was measured at $10.53 \mathrm{~S} / \mathrm{cm}$ which fared better than separated fiber mats $(7.34 \mathrm{~S} / \mathrm{cm})$. The charge capacity and electrical conductivity of interconnected fiber mats were enhanced by the incorporation of $12.6 \mathrm{wt} \%$ nitrogen to the surface (Table 3). The initial discharge curves of carbon fibers showed the plateau corresponding to SEI formation around $1.2 \mathrm{~V}$ which disappeared for $\mathrm{N}$-doped carbon fibers. Therefore, SEI formation was hindered by $\mathrm{N}$-doping and the initial capacity loss was reduced.
Dalton et al. (2019) reported that the electrical conductivity of lignin-electrospun CNFs produced at 900 and $1100^{\circ} \mathrm{C}$ with $70 \%$ lignin is 9.65 and $24.47 \mathrm{~S} / \mathrm{cm}$, respectively. This enhancement in the electrical conductivity resulted from increasing the degree of graphitization. These new CNF materials with both n-type and p-type semiconducting behaviors can be used in thermoelectric generators.

Zhao et al. (2018) fabricated a new sustainable carbon fiber from lignin/PVA as a highly efficient and binder-free counter electrode for DSSCs. The new electrode of DSSCs has a conversion efficiency of $7.60 \%$ which can be used as a substitute to expensive and commercial Pt electrodes (conversion efficiency of 7.67\%). García-Mateos et al. (2017) also assembled new Ptcontaining carbon fibers which are applied as electrodes with no conductivity promoter or binder.

Various types of carbon materials such as graphene, carbon nanotubes and activated carbon have been reported to manufacture electrodes for supercapacitors. Lignin-carbon fiber has been studied in different publication to manufacture electrodes for capacitors/supercapacitors (Fang et al., 2017b; Lei et al., 2017; Ma et al., 2018; Yu et al., 2018; Perera Jayawickramage et al., 2019; Roman et al., 2019; Schlee et al., 2019a,b; Yun et al., 2019). Lai et al. (2014b) applied lignin-carbon fibers as electrodes to prepare electrochemical supercapacitors as summarized in Table 4. The highest gravimetric capacitance was obtained with high alkali lignin content $(70 \%)$ due to the increase in surface area and decreasing in pore size of fibers. During the test, the electrodes were electrochemically stable or durable.

Figure 6 displayed the cyclic voltametry of lignin/PVA with differernt surfactant which presented largest loop area and superior electrical double-layer capacitive behavior except for carbon fiber with nonionic surfactant Triton X-100 (CNF-TX) (Fang et al., 2017b). CNF with 1.0\% anionic surfactant sodium dodecyl sulfate displayed the longest discharge time which resulted in better material capacitance. 
TABLE 4 | Electrochemical properties of carbonized fibers as supercapacitor.

\begin{tabular}{|c|c|c|c|c|c|}
\hline $\begin{array}{l}\text { Precursor fiber material } \\
\text { used for supercapacitor }\end{array}$ & $\begin{array}{l}\text { Gravimetric capacitance } \\
\left(\mathrm{F} \mathrm{g}^{-1}\right)\end{array}$ & $\begin{array}{l}\text { Energy density } \\
\left(\mathrm{W} \mathrm{h} \mathrm{kg}^{-1}\right)\end{array}$ & $\begin{array}{l}\text { Power density } \\
\left(\mathbf{k W ~ k g}^{-1}\right)\end{array}$ & Stability & References \\
\hline $\begin{array}{l}\text { Lignin/Polyvinyl alcohol: } \\
70 / 30\end{array}$ & $\begin{array}{l}64\left(\text { at } 400 \mathrm{~mA} \mathrm{~g}^{-1}\right) 50 \text { (at } \\
2000 \mathrm{~mA} \mathrm{~g}^{-1} \text { ) }\end{array}$ & 5.67 & 94.19 & Dropped $10 \%$ after 6000 cycle & Lai et al., 2014b \\
\hline $\begin{array}{l}\text { Lignin/Polyvinyl } \\
\text { alcohol/ } \mathrm{MnO}_{2}\end{array}$ & 83.3 & 84.3 & 5.72 & & Ma et al., 2016 \\
\hline $\begin{array}{l}\text { Lignin/PVA with different } \\
\text { surfactant }\end{array}$ & $\begin{array}{l}\text { CNF-C: } 66.3 \text { CNF-SDS: } \\
80.7 \text { CNF-DTAB:62.6 } \\
\text { CNF-TX: } 34\end{array}$ & - & - & - & Fang et al., 2017b \\
\hline $\begin{array}{l}\mathrm{NiCO}_{2} \mathrm{O}_{4} \text { oxides-decorated } \\
\text { Lignin/PAN }\end{array}$ & $\begin{array}{l}\sim 1757\left(\text { at } 2 \mathrm{~mA} \mathrm{~cm}^{-2}\right) \\
34.3\left(\text { at } 1 \mathrm{~A} \mathrm{~g}^{-1}\right)\end{array}$ & 47.75 & 799.53 & $\begin{array}{l}\sim 138 \% \text { capacitance retention } \\
\text { after } 5000 \text { cycles at } 7 \mathrm{~mA} \mathrm{~cm}^{-2}\end{array}$ & Lei et al., 2017 \\
\hline $\begin{array}{l}\text { Lignin/PVP+ } \\
\mathrm{Mg}\left(\mathrm{NO}_{3}\right)_{2} \cdot 6 \mathrm{H}_{2} \mathrm{O} \text { as additive }\end{array}$ & $248\left(\right.$ at $\left.0.2 \mathrm{~A} \mathrm{~g}^{-1}\right)$ & - & - & $\begin{array}{l}\text { 97\% capacitance retention } \\
\text { after } 1000 \text { cycles at } 20 \mathrm{~A} \mathrm{~g}^{-1}\end{array}$ & Ma et al., 2018 \\
\hline $\begin{array}{l}\text { Acetic acid lignin/PEO/ } \\
\text { SAN/Iron oxide }\end{array}$ & $121\left(\right.$ at $\left.0.5 \mathrm{~A} \mathrm{~g}^{-1}\right)$ & - & - & $\begin{array}{l}\text { 90\% retention rate after } 1000 \\
\text { cycles }\end{array}$ & Yu et al., 2018 \\
\hline Lignin/PAN (30/70) & $128\left(\right.$ at $\left.1 \mathrm{~A} \mathrm{~g}^{-1}\right)$ & 59 & 15 & $75 \%$ retention after 1000 cycles & $\begin{array}{l}\text { Perera } \\
\text { Jayawickramage et al., } \\
2019\end{array}$ \\
\hline Lignin/PVA & $\begin{array}{l}\text { Mat: } 7.73 \text { Twist } 23 \\
\text { turns/cm: } 0.33\end{array}$ & - & - & - & Roman et al., 2019 \\
\hline Lignin/PEO & $\begin{array}{l}151 \text { without } \mathrm{NaNO}_{3}, 192 \\
\text { with } \mathrm{NaNO}_{3}\end{array}$ & 8.4 & 60 & $\begin{array}{l}92.5 \% \text { retention after } 6000 \\
\text { cycles }\end{array}$ & Schlee et al., 2019a \\
\hline $\begin{array}{l}\text { Lignin non-activated Lignin } \\
\mathrm{CO}_{2} \text {-activated }\end{array}$ & $\begin{array}{l}155\left(\text { at } 0.1 \mathrm{~A} \mathrm{~g}^{-1}\right) 113 \text { (at } \\
\left.250 \mathrm{~A} \mathrm{~g}^{-1}\right)\end{array}$ & 1.24 & 4152 & $94 \%$ retention after 6000 cycles & Schlee et al., 2019b \\
\hline PAN/pitch/lignin With ZnO & 165 (at $1 \mathrm{~mA} \mathrm{~cm}-2$ ) & 22 & 0.4 & $6 \%$ reduced after 3000 cycles & Yun et al., 2019 \\
\hline
\end{tabular}
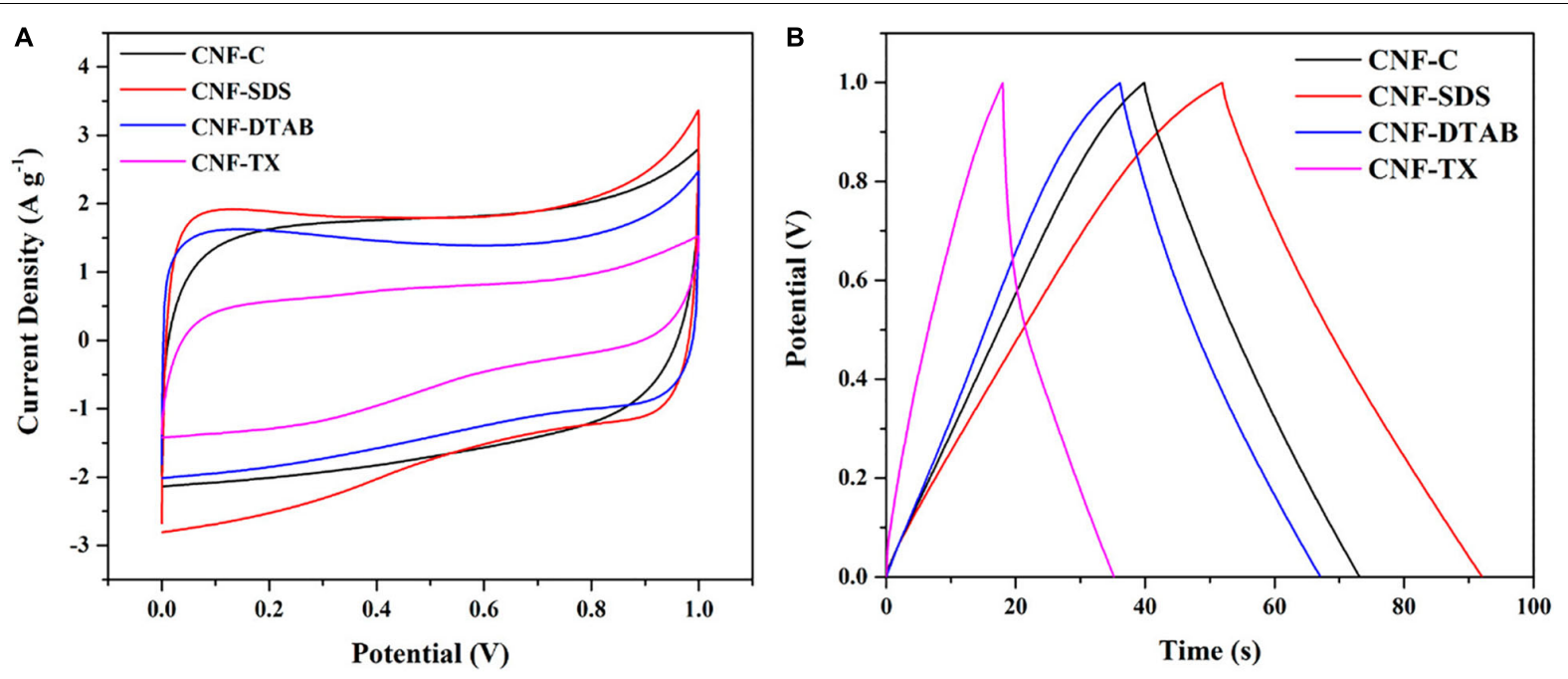

FIGURE 6 | Electrochemical characterizations of carbon fiber membranes from solutions with varying surfactants. (A) Cyclic voltammograms curves at 50 mv $\mathrm{s}^{-1}$; (B) galvanostatic charge-discharge curves at $1 \mathrm{~A} \mathrm{~g}^{-1}$. The carbonized mats were labeled as CNF-C, CNF-SDS, CNF-DTAB, and CNF-TX for fibers spun from solutions without surfactant, 1.0\% SDS (Anionic surfactant sodium dodecyl sulfate), 1.0\% DTAB (Cationic surfactant N, N, N-trimethyl-1-dodecanaminium bromide), and 1.0\% TX-100 (Nonionic surfactant Triton X-100), respectively. Fang et al. (2017b) with permission from the American Chemical Society.

Due to high surface area, high gas permeability and high porosity, lignin-carbon fiber is applied as an adsorbent for water purification and adsorption of volatile organic compounds (Beck et al., 2017; Song et al., 2017, 2019; Zhang et al., 2019). Zhang et al. (2019) prepared a nanocarbon fiber membrane from Lignin/PVA to adsorb cationic dye (Safranine T). The adsorbent membrane showed superior desorption behavior with the ability to be recycled with constant adsorption performance.
These accomplishments suggest the possible utilization of lignin-carbon fibers for a wide variety of applications, such as supercapacitors, separation, electrodes, catalysis and dye-synthesized solar cells (DSSCs) (Fang et al., 2017a; Zhao et al., 2018; Cao et al., 2020). However, these sustainable materials should be enhanced further especially the mechanical properties and scale-up for industrial commercialization. Recent reviews showed a different technology to scale-up the 
electrospinning process for biomedical applications (Vass et al., 2020). The technology of co-axial and multi-axial system offer an opportunity for industrial scale-up of electrospinning.

\section{CONCLUSION}

Electrospun fibers have been used as precursors for the production of carbon nanofibers. Electrospinning is a convenient method for the spinning of thermally sensitive biopolymers. This method provides an easy way for the incorporation of metal particles and fillers in the fibers. Additionally, nanofibers have exceptional properties like high surface area and porosity, which is valuable for multiple applications. Due to increasing environmental awareness, renewable resource-based and sustainable materials have been studied as an alternative to the petroleum-based materials. Electrospinning of biopolymer lignin fibers and conversion to carbonized fibers have been studied to develop a convenient process for the production of lignin fibers and carbon fibers. Carbon fibers have been characterized to determine their morphology, physical properties and degree of graphitization. Energy storage devices mainly batteries and supercapacitors have been fabricated by using lignin-based carbon fibers and tested. Promising results have shown these materials have the potential for the next generation of renewable electronics and energy storage devices.

The limitation of lignin-based carbon fiber is the heterogeneity and diversity of lignin which resulted in different characteristic of the fiber produced. By lowering the cost of organosolv lignin, it can be an excellent candidate to overcome this shortage. Another limitation is the necessity of scaling up electrospinning for industrial commercialization, which is the one of the main challenges for electrospinning of polymers. The technology of

\section{REFERENCES}

Abdelwahab, M. A., Misra, M., and Mohanty, A. K. (2019). Injection molded biocomposites from polypropylene and lignin: ewffect of compatibilizers on interfacial adhesion and performance. Ind. Crops Prod. 132, 497-510. doi: 10. 1016/j.indcrop.2019.02.026

Abdelwahab, M. A., Taylor, S., Misra, M., and Mohanty, A. K. (2015). Thermomechanical characterization of bioblends from polylactide and poly(butylene adipate-co-terephthalate) and lignin. Macromol. Mater. Eng. 300, 299-311. doi: 10.1002/mame.201400241

Achyuthan, K. E., Achyuthan, A. M., Adams, P. D., Dirk, S. M., Harper, J. C., Simmons, B. A., et al. (2010). Supramolecular self-assembled chaos: polyphenolic lignin's barrier to cost-effective lignocellulosic biofuels. Molecules 15, 8641-8688. doi: 10.3390/molecules 15118641

Adams, B., Abdelwahab, M., Misra, M., and Mohanty, A. K. (2018). Injectionmolded bioblends from lignin and biodegradable polymers: processing and performance evaluation. J. Polym. Environ. 26, 2360-2373. doi: 10.1007/ s10924-017-1132-0

adil, K. R., Mussatto, S. I., and Jha, H. (2018). Synthesis and characterization of silver nanoparticles loaded poly(vinyl alcohol)-lignin electrospun nanofibers and their antimicrobial activity. Int. J. Biol. Macromol. 120, 763-767. doi: 10. 1016/j.ijbiomac.2018.08.109

Ago, M., Jakes, J. E., Johansson, L.-S., Park, S., and Rojas, O. J. (2012a). Interfacial properties of lignin-based electrospun nanofibers and films reinforced with cellulose nanocrystals. ACS Appl. Mater. Interfaces 4, 6849-6856. doi: 10.1021/ am302008p co-axial and multi-axial system offer an opportunity for industrial scale-up of electrospinning.

The challenge of lignin-based carbon fiber is to apply these fibers in the composite application especially in the automotive industry and in biomedical applications such as facemasks, and shields which are in short supply during global pandemics. Promising results have shown these materials have the potential for the next generation of renewable electronics and energy storage devices. New studies are proceeding to investigate further ways to improve the processing efficiency and determine process-property relationships such as effects of electrospun fiber orientation on the conductivity of the carbonized fibers. These detailed studies will help to further tailor the fiber properties for targeted applications.

\section{AUTHOR CONTRIBUTIONS}

All authors listed have made a substantial, direct and intellectual contribution to the work, and approved it for publication.

\section{FUNDING}

The authors are thankful for the financial support from the Natural Sciences and Engineering Research Council (NSERC), Canada, for the Discovery grants individual Project \# 400320; the Ontario Ministry of Agriculture, Food and Rural Affairs (OMAFRA) - University of Guelph Bioeconomy Industrial Uses Research Program Project \# 030332; the Ontario Research Fund, Research Excellence Program; and Round-7 (ORF-RE07) from the Ontario Ministry of Research Innovation and Science (MRIS) (Projects \# 052644 and \#052665).

Ago, M., Okajima, K., Jakes, J. E., Park, S., and Rojas, O. J. (2012b). Lignin-based electrospun nanofibers reinforced with cellulose nanocrystals. Biomacromolecules 13, 918-926. doi: 10.1021/bm201828g

Ago, M., Jakes, J. E., and Rojas, O. J. (2013). Thermomechanical properties of lignin-based electrospun nanofibers and films reinforced with cellulose nanocrystals: a dynamic mechanical and nanoindentation study. ACS App. Mater. Interfaces 5, 11768-11776. doi: 10.1021/am403451w

Ahn, Y., Kang, Y., Park, B., Ku, M. K., Lee, S. H., and Kim, H. (2014). Influence of lignin on rheological behaviors and electrospinning of polysaccharide solution. J. Appl. Poly. Sci. 131, 40031-40037. doi: 10.1002/app.40031

Alghoraibi, I., and Alomari, S. (2018). "Different methods for nanofiber design and fabrication," in Handbook of Nanofibers, eds A. Barhoum, M. Bechelany, and A. Makhlouf (Cham: Springer International Publishing), 1-46. doi: 10.1007/9783-319-42789-8_11-2

Aslanzadeh, S., Ahvazi, B., Boluk, Y., and Ayranci, C. (2017). Carbon fiber production from electrospun sulfur free softwood lignin precursors. J. Eng. Fiber. Fabr. 12:155892501701200405. doi: 10.1177/155892501701200405

Bahi, A., Shao, J., Mohseni, M., and Ko, F. K. (2017). Membranes based on electrospun lignin-zeolite composite nanofibers. Sep. Purif. Technol. 187, 207213. doi: 10.1016/j.seppur.2017.06.015

Baker, D. A., and Rials, T. G. (2013). Recent advances in low-cost carbon fiber manufacture from lignin. J. Appl. Polym. Sci. 130, 713-728. doi: 10.1002/app. 39273

Beachley, V., and Wen, X. (2009). Effect of electrospinning parameters on the nanofiber diameter and length. Mater. Sci. Eng. C 29, 663-668. doi: 10.1016/ j.msec.2008.10.037 
Beck, R. J., Zhao, Y., Fong, H., and Menkhaus, T. J. (2017). Electrospun lignin carbon nanofiber membranes with large pores for highly efficient adsorptive water treatment applications. J. Water Process Eng. 16, 240-248. doi: 10.1016/j. jwpe.2017.02.002

Beisl, S., Friedl, A., and Miltner, A. (2017). Lignin from micro- to nanosize: applications. Int. J. Mol. Sci. 18:2367. doi: 10.3390/ijms18112367

Bengtsson, A., Bengtsson, J., Sedin, M., and Sjöholm, E. (2019). Carbon fibers from lignin-cellulose precursors: effect of stabilization conditions. ACS Sust. Chem. Eng. 7, 8440-8448. doi: 10.1021/acssuschemeng.9b00108

Bengtsson, A., Hecht, P., Sommertune, J., Ek, M., Sedin, M., and Sjöholm, E. (2020). Carbon fibers from lignin-cellulose precursors: effect of carbonization conditions. ACS Sust. Chem. Eng. 8, 6826-6833. doi: 10.1021/acssuschemeng. 0c01734

Berenguer, R., Garcia-Mateos, F. J., Ruiz-Rosas, R., Cazorla-Amoros, D., Morallon, E., Rodriguez-Mirasol, J., et al. (2015). Biomass-derived binderless fibrous carbon electrodes for ultrafast energy storage. Green Chemi. 18, 1506-1515. doi: 10.1039/C5GC02409A

Bhardwaj, N., and Kundu, S. C. (2010). Electrospinning: a fascinating fiber fabrication technique. Biotechnol. Adv. 28, 325-347. doi: 10.1016/j.biotechadv. 2010.01.004

Blanco López, M. C., Blanco, C. G., Martı̀nez-Alonso, A., and Tascón, J. M. D. (2002). Composition of gases released during olive stones pyrolysis. J. Anal. Appl. Pyrol. 65, 313-322. doi: 10.1016/S0165-2370(02)00008-6

Braun, J. L., Holtman, K. M., and Kadla, J. F. (2005). Lignin-based carbon fibers: oxidative thermostabilization of kraft lignin. Carbon 43, 385-394. doi: 10.1016/ j.carbon.2004.09.027

Britt, P. F., Buchanan, A. C. III, and Malcolm, E. A. (1995). Thermolysis of phenethyl phenyl ether: a model for ether linkages in lignin and low rank coal. J. Org. Chem. 60, 6523-6536. doi: 10.1021/jo00125a044

Britt, P. F., Buchanan, A. C., Cooney, M. J., and Martineau, D. R. (2000a). Flash vacuum pyrolysis of methoxy-substituted lignin model compounds. J. Org. Chem. 65, 1376-1389. doi: 10.1021/jo991479k

Britt, P. F., Buchanan, A. C., and Malcolm, E. A. (2000b). Impact of restricted mass transport on pyrolysis pathways for aryl ether containing lignin model compounds. Energy Fuels 14, 1314-1322. doi: 10.1021/ef000160w

Caballero, A., Hernán, L., and Morales, J. (2011). Limitations of disordered carbons obtained from biomass as anodes for real lithium-ion batteries. ChemSusChem 4, 658-663. doi: 10.1002/cssc.201000398

Camiré, A., Espinasse, J., Chabot, B., and Lajeunesse, A. (2020). Development of electrospun lignin nanofibers for the adsorption of pharmaceutical contaminants in wastewater. Environ. Sci. Pollut. Res. 27, 3560-3573. doi: 10. 1007/s11356-018-3333-z

Cançado, L. G., Takai, K., Enoki, T., Endo, M., Kim, Y. A., Mizusaki, H., et al. (2006). General equation for the determination of the crystallite size La of nanographite by Raman spectroscopy. Appl. Phys. Lett. 88:163106. doi: 10.1063/ 1.2196057

Cao, Q., Zhu, M., Chen, J., Song, Y., Li, Y., and Zhou, J. (2020). Novel lignincellulose-based carbon nanofibers as high-performance supercapacitors. ACS Appl. Mater. Interfaces 12, 1210-1221. doi: 10.1021/acsami.9b14727

Chatterjee, S., and Saito, T. (2015). Lignin-derived advanced carbon materials. Chem. Eur. 8, 3941-3958. doi: 10.1002/cssc.201500692

Chen, R., Abdelwahab, M. A., Misra, M., and Mohanty, A. K. (2014). Biobased ternary blends of lignin, poly(Lactic Acid), and Poly(Butylene Adipateco-Terephthalate): the effect of lignin heterogeneity on blend morphology and compatibility. J. Polym. Environ. 22, 439-448. doi: 10.1007/s10924-0140704-5

Cho, M., Karaaslan, M., Wang, H., and Renneckar, S. (2018). Greener transformation of lignin into ultralight multifunctional materials. J. $f$ Mater. Chem. A 6, 20973-20981. doi: 10.1039/C8TA07802E

Cho, M., Karaaslan, M. A., Renneckar, S., and Ko, F. (2017). Enhancement of the mechanical properties of electrospun lignin-based nanofibers by heat treatment. J. Mater. Sci. 52, 9602-9614. doi: 10.1007/s10853-017-1160-0

Cho, M., Ko, F. K., and Renneckar, S. (2019a). Impact of thermal oxidative stabilization on the performance of lignin-based carbon nanofiber mats. ACS Omega 4, 5345-5355. doi: 10.1021/acsomega.9b00278

Cho, M., Ko, F. K., and Renneckar, S. (2019b). Molecular orientation and organization of technical lignin-based composite nanofibers and films. Biomacromolecules 20, 4485-4493. doi: 10.1021/acs.biomac.9b01242
Choi, D., Lee, J.-N., Song, J., Kang, P.-H., Park, J.-K., and Lee, Y. (2013). Fabrication of polyacrylonitrile/lignin-based carbon nanofibers for high-power lithium ion battery anodes. J. Solid State Electrochem. 17, 2471-2475. doi: 10.1007/s10008013-2112-5

Culebras, M., Geaney, H., Beaucamp, A., Upadhyaya, P., Dalton, E., Ryan, K. M., et al. (2019). Bio-derived carbon nanofibres from lignin as highperformance li-ion anode materials. ChemSusChem 12, 4516-4521. doi: 10. 1002/cssc.201901562

Dai, Z., Ren, P.-G., Jin, Y.-L., Zhang, H., Ren, F., and Zhang, Q. (2019). Nitrogensulphur Co-doped graphenes modified electrospun lignin/polyacrylonitrilebased carbon nanofiber as high performance supercapacitor. J. Power Sour. 437:226937. doi: 10.1016/j.jpowsour.2019.226937

Dallmeyer, I., Chowdhury, S., and Kadla, J. F. (2013). Preparation and characterization of kraft lignin-based moisture-responsive films with reversible shape-change capability. Biomacromolecules 14, 2354-2363. doi: 10.1021/ bm400465p

Dallmeyer, I., Ko, F., and Kadla, J. F. (2010). Electrospinning of technical lignins for the production of fibrous networks. J. Wood Chem. Technol. 30, 315-329. doi: 10.1080/02773813.2010.527782

Dallmeyer, I., Lin, L. T., Li, Y., Ko, F., and Kadla, J. F. (2014). Preparation and characterization of interconnected, kraft lignin-based carbon fibrous materials by electrospinning. Macromol. Mater. Eng. 299, 540-551. doi: 10.1002/mame. 201300148

Dalton, N., Lynch, R. P., Collins, M. N., and Culebras, M. (2019). Thermoelectric properties of electrospun carbon nanofibres derived from lignin. Int. J. Biol. Macromo. 121, 472-479. doi: 10.1016/j.ijbiomac.2018.10.051

Davé, V., Prasad, A., Marand, H., and Glasser, W. G. (1993). Molecular organization of lignin during carbonization. Polymer 34, 3144-3154. doi: 10. 1016/0032-3861(93)90382-K

Deitzel, J. M., Kleinmeyer, J., Harris, D., and Beck Tan, N. C. (2001). The effect of processing variables on the morphology of electrospun nanofibers and textiles. Polymer 42, 261-272. doi: 10.1016/S0032-3861(00)00250-0

Demiroğlu Mustafov, S., Mohanty, A. K., Misra, M., and . Ö, M. (2019). Fabrication of conductive Lignin/PAN carbon nanofibers with enhanced graphene for the modified electrodes. Carbon 147, 262-275. doi: 10.1016/j.carbon.2019.02.058

Dessureault, D. (2014). Biofuels Annual 2014 - Canada. Washington, DC: USDA Foreign Agricultural Service.

Fang, W., Yang, S., Wang, X.-L., Yuan, T.-Q., and Sun, R.-C. (2017a). Manufacture and application of lignin-based carbon fibers (LCFs) and lignin-based carbon nanofibers (LCNFs). Green Chem. 19, 1794-1827. doi: 10.1039/C6GC03206K

Fang, W., Yang, S., Yuan, T.-Q., Charlton, A., and Sun, R.-C. (2017b). Effects of various surfactants on alkali lignin electrospinning ability and spun fibers. Ind. Eng. Chem. Res. 56, 9551-9559. doi: 10.1021/acs.iecr.7b02494

Fenner, R. A., and Lephardt, J. O. (1981). Examination of the thermal decomposition of kraft pine lignin by Fourier transform infrared evolved gas analysis. J. Agric. Food Chem. 29, 846-849. doi: 10.1021/jf00106a042

Ferrari, A. C., and Robertson, J. (2000). Interpretation of Raman spectra of disordered and amorphous carbon. Phys. Rev. B 61, 14095-14107. doi: 10.1103/ physrevb.61.14095

Fey, G. T.-K., Lee, D. C., Lin, Y. Y., and Kumar, T. P. (2003). High-capacity disordered carbons derived from peanut shells as lithium-intercalating anode materials. Synth. Metals 139, 71-80. doi: 10.1016/S0379-6779(03)00082-1

Foston, M., Nunnery, G. A., Meng, X., Sun, Q., Baker, F. S., and Ragauskas, A. (2013). NMR a critical tool to study the production of carbon fiber from lignin. Carbon 52, 65-73. doi: 10.1016/j.carbon.2012.09.006

Furuno, T., Sasabe, H., and Ikegami, A. (1998). Imaging two-dimensional arrays of soluble proteins by atomic force microscopy in contact mode using a sharp supertip. Ultramicroscopy 70, 125-131. doi: 10.1016/S0304-3991(97)00103-4

Gao, G., Ko, F., and Kadla, J. F. (2015). Synthesis of noble monometal and bimetalmodified lignin nanofibers and carbon nanofibers through surface-grafted Poly(2-(Dimethylamino)Ethyl Methacrylate) brushes. Macromol. Mater. Eng. 300, 836-847. doi: 10.1002/mame.201500006

García-Mateos, F. J., Berenguer, R., Valero-Romero, M. J., Rodríguez-Mirasol, J., and Cordero, T. (2018). Phosphorus functionalization for the rapid preparation of highly nanoporous submicron-diameter carbon fibers by electrospinning of lignin solutions. J. Materi. Chem. A 6, 1219-1233. doi: 10.1039/C7TA08788H

García-Mateos, F. J., Cordero-Lanzac, T., Berenguer, R., Morallón, E., CazorlaAmorós, D., Rodríguez-Mirasol, J., et al. (2017). Lignin-derived Pt supported 
carbon (submicron)fiber electrocatalysts for alcohol electro-oxidation. Appl. Catal. BEnviron. 211, 18-30. doi: 10.1016/j.apcatb.2017.04.008

García-Mateos, F. J., Ruiz-Rosas, R., Rosas, J. M., Rodríguez-Mirasol, J., and Cordero, T. (2019). Controlling the composition, morphology, porosity, and surface chemistry of lignin-based electrospun carbon materials. Front. Mater. 6:114. doi: 10.3389/fmats.2019.00114

Guo, Z., Liu, Z., Ye, L., Ge, K., and Zhao, T. (2015). The production of ligninphenol-formaldehyde resin derived carbon fibers stabilized by BN preceramic polymer. Mater. Lett. 142, 49-51. doi: 10.1016/j.matlet.2014.11.068

Han, D., and Steckl, A. J. (2019). Coaxial electrospinning formation of complex polymer fibers and their applications. ChemPlusChem 84, 1453-1497. doi: 10. $1002 /$ cplu. 201900281

Hatakeyama, H., and Hatakeyama, T. (2010). Lignin structure. Properties and applications. Adv. Polym. Sci. 232, 1-63. doi: 10.1007/12_2009_12

Hishida, M., Shikinaka, K., Inazawa, M., Katayama, Y., Kajita, S., Masai, E., et al. (2009). Conductive cements based polyesters of PDC(2-Pyrone-4,6Dicarboxylic Acid) obtained from a metabolic intermediate of lignin. Kobunshi Ronbunshu 66, 141-146. doi: 10.1295/koron.66.141

$\mathrm{Hu}, \mathrm{S}$., and Hsieh, Y.-L. (2013). Ultrafine microporous and mesoporous activated carbon fibers from alkali lignin. J. Mater. Chem. A 1, 11279-11288. doi: 10.1039/ C3TA12538F

Hu, S., Zhang, S., Pan, N., and Hsieh, Y.-L. (2014). High energy density supercapacitors from lignin derived submicron activated carbon fibers in aqueous electrolytes. J. Power Sour. 270, 106-112. doi: 10.1016/j.jpowsour.2014. 07.063

Huang, Z.-M., Zhang, Y. Z., Kotaki, M., and Ramakrishna, S. (2003). A review on polymer nanofibers by electrospinning and their applications in nanocomposites. Compos. Sci. Technol. 63, 2223-2253. doi: 10.1016/S02663538(03)00178-7

Inagaki, M., Yang, Y., and Kang, F. (2012). carbon nanofibers prepared via electrospinning. Adv. Mater. 24, 2547-2566. doi: 10.1002/adma.201104940

Jawhari, T., Roid, A., and Casado, J. (1995). Raman spectroscopic characterization of some commercially available carbon black materials. Carbon 33, 1561-1565. doi: 10.1016/0008-6223(95)00117-V

Jia, H., Sun, N., Dirican, M., Li, Y., Chen, C., Zhu, P., et al. (2018). Electrospun kraft lignin/cellulose acetate-derived nanocarbon network as an anode for high-performance sodium-ion batteries. ACS Appl. Mater. Interfaces 10, 4436844375. doi: 10.1021 /acsami.8b13033

Jin, J., Yu, B.-J., Shi, Z.-Q., Wang, C.-Y., and Chong, C.-B. (2014). Ligninbased electrospun carbon nanofibrous webs as free-standing and binder-free electrodes for sodium ion batteries. J. Power Sour. 272, 800-807. doi: 10.1016/j. jpowsour.2014.08.119

Kadla, J. F., and Kubo, S. (2003). Miscibility and hydrogen bonding in blends of poly(ethylene oxide) and kraft lignin. Macromolecules 36, 7803-7811. doi: $10.1021 / \mathrm{ma} 0348371$

Kadla, J. F., and Kubo, S. (2004). Lignin-based polymer blends: analysis of intermolecular interactions in lignin-synthetic polymer blends. Compos. Part AAppl. Sci. Manufactur. 35, 395-400. doi: 10.1016/j.compositesa.2003.09.019

Kadla, J. F., Kubo, S., Venditti, R. A., Gilbert, R. D., Compere, A. L., and Griffith, W. (2002). Lignin-based carbon fibers for composite fiber applications. Carbon 40, 2913-2920. doi: 10.1016/S0008-6223(02)00248-8

Kai, D., Tan, M. J., Chee, P. L., Chua, Y. K., Yap, Y. L., and Loh, X. J. (2016). Towards lignin-based functional materials in a sustainable world. Green Chemistry 18, 1175-1200. doi: 10.1039/C5GC02616D

Keskar, G., Rao, R., Luo, J., Hudson, J., Chen, J., and Rao, A. M. (2005). Growth, nitrogen doping and characterization of isolated single-wall carbon nanotubes using liquid precursors. Chem. Phys. Lett. 412, 269-273. doi: 10.1016/j.cplett. 2005.07.007

Kim, C., Yang, K. S., Kojima, M., Yoshida, K., Kim, Y. J., Kim, Y. A., et al. (2006). Fabrication of electrospinning-derived carbon nanofiber webs for the anode material of lithium-ion secondary batteries. Adv. Funct. Mater. 16, 2393-2397. doi: 10.1002/adfm.200500911

Köhler, T., Brüll, R., Pursche, F., Langgartner, J., Seide, G., and Gries, T. (2017). High strength and low weight hollow carbon fibres. IOP Conf. Ser. Mater. Sci. Eng. 254:042017. doi: 10.1088/1757-899x/254/4/042017

Kubo, S., and Kadla, J. F. (2004). Poly(Ethylene Oxide)/Organosolv lignin blends: relationship between thermal properties. Chem. Struct. Blend Beha. Macromol. 37, 6904-6911. doi: 10.1021/ma0490552
Kubo, S., and Kadla, J. F. (2005). Lignin-based carbon fibers: effect of synthetic polymer blending on fiber properties. J. Polym. Environ. 13, 97-105. doi: 10. 1007/s10924-005-2941-0

Kubo, S., and Kadla, J. F. (2006). Effect of poly(ethylene oxide) molecular mass on miscibility and hydrogen bonding with lignin. Holzforschung 60, 245-252. doi: 10.1515/hf.2006.040

Kumar, M., Hietala, M., and Oksman, K. (2019). Lignin-Based electrospun carbon nanofibers. Front. Mater. 6:62. doi: 10.3389/fmats.2019.00062

Kumar, M. N. S., Mohanty, A. K., Erickson, L., and Misra, M. (2009). Lignin and its applications with polymers. J. Biobased Mater. Bioener. 3, 1-24. doi: 10.1166/jbmb.2009.1001

Kumar, P. R., Khan, N., Vivekanandhan, S., Satyanarayana, N., Mohanty, A. K., and Misra, M. (2012). Nanofibers: effective generation by electrospinning and their applications. J. Nanosci. Nanotechnol. 12, 1-25. doi: 10.1166/jnn.2012.5111

Lai, C., Kolla, P., Zhao, Y., Fong, H., and Smirnova, A. L. (2014a). Ligninderived electrospun carbon nanofiber mats with supercritically deposited Ag nanoparticles for oxygen reduction reaction in alkaline fuel cells. Electrochim. Acta 130, 431-438. doi: 10.1016/j.electacta.2014.03.006

Lai, C., Zhou, Z., Zhang, L., Wang, X., Zhou, Q., Zhao, Y., et al. (2014b). Free-standing and mechanically flexible mats consisting of electrospun carbon nanofibers made from a natural product of alkali lignin as binder-free electrodes for high-performance supercapacitors. J. Power Sour. 247, 134-141. doi: 10. 1016/j.jpowsour.2013.08.082

Lallave, M., Bedia, J., Ruiz-Rosas, R., Rodrí-guez-Mirasol, J., Cordero, T., Otero, J. C., et al. (2007). Filled and hollow carbon nanofibers by coaxial electrospinning of alcell lignin without binder polymers. Adv. Mater. 19, 42924296. doi: 10.1002/adma.200700963

Laurichesse, S., and Avérous, L. (2014). Chemical modification of lignins: towards biobased polymers. Prog. Polym. Sci. Top. Issue Biomater. 39, 1266-1290. doi: 10.1016/j.progpolymsci.2013.11.004

Lee, E.-S., Kim, Y.-O., Ha, Y.-M., Lim, D., Hwang, J. Y., Kim, J., et al. (2018). Antimicrobial properties of lignin-decorated thin multi-walled carbon nanotubes in poly(vinyl alcohol) nanocomposites. Eur. Poly. J. 105, 79-84. doi: 10.1016/j.eurpolymj.2018.05.014

Lei, D., Li, X.-D., Seo, M.-K., Khil, M.-S., Kim, H.-Y., and Kim, B.-S. (2017). NiCo2O4 nanostructure-decorated PAN/lignin based carbon nanofiber electrodes with excellent cyclability for flexible hybrid supercapacitors. Polymer 132, 31-40. doi: 10.1016/j.polymer.2017.10.051

Li, X., Chen, Y., Huang, H., Mai, Y.-W., and Zhou, L. (2016). Electrospun carbonbased nanostructured electrodes for advanced energy storage - A review. Energy Storage Mater. 5, 58-92. doi: 10.1016/j.ensm.2016.06.002

Li, Z., Xu, Z., Tan, X., Wang, H., Holt, C. M. B., Stephenson, T., et al. (2013). Mesoporous nitrogen-rich carbons derived from protein for ultra-high capacity battery anodes and supercapacitors. Energy Environ. Sci. 6, 871-878. doi: 10. 1039/C2EE23599D

Li, Z., and Wang, C. (eds). (2013). "Effects of working parameters on electrospinning," in One-Dimensional Nanostructures: Electrospinning Technique and Unique Nanofibers (Berlin: Springer Berlin Heidelberg), 15-28. doi: 10.1007/978-3-642-36427-3_2

Liu, H. C., Chien, A.-T., Newcomb, B. A., Liu, Y., and Kumar, S. (2015). Processing, Structure, and properties of lignin- and CNT-Incorporated polyacrylonitrilebased carbon fibers. ACS Sust. Chem. Eng. 3, 1943-1954. doi: 10.1021/ acssuschemeng.5b00562

Liu, W.-J., Jiang, H., and Yu, H.-Q. (2015). Thermochemical conversion of lignin to functional materials: a review and future directions. Green Chem. 17, 48884907. doi: 10.1039/C5GC01054C

Liu, S., Cheng, X., He, Z., Liu, J., Zhang, X., Xu, J., et al. (2020). Amine-terminated highly cross-linked polyphosphazene-functionalized carbon nanotube-reinforced lignin-based electrospun carbon nanofibers. ACS Sust. Chem. Eng. 8, 1840-1849. doi: 10.1021/acssuschemeng.9b05940

Liu, Y., and Kumar, S. (2012). Recent progress in fabrication. Structure, and properties of carbon fibers. Polym. Rev. 52, 234-258. doi: 10.1080/15583724. 2012.705410

Lora, J. H., and Glasser, W. G. (2002). Recent industrial applications of lignin: a sustainable alternative to nonrenewable materials. J. Polym. Environ. 10, 39-48. doi: 10.1023/A:1021070006895

Ma, X., Kolla, P., Zhao, Y., Smirnova, A. L., and Fong, H. (2016). Electrospun lignin-derived carbon nanofiber mats surface-decorated with $\mathrm{MnO}_{2}$ 
nanowhiskers as binder-free supercapacitor electrodes with high performance. J. Power Sources 325, 541-548. doi: 10.1016/j.jpowsour.2016.06.073

Ma, C., Li, Z., Li, J., Fan, Q., Wu, L., Shi, J., et al. (2018). Lignin-based hierarchical porous carbon nanofiber films with superior performance in supercapacitors. Appl. Surface Sci. 456, 568-576. doi: 10.1016/j.apsusc.2018.06.189

Ma, X., Smirnova, A. L., and Fong, H. (2019). Flexible lignin-derived carbon nanofiber substrates functionalized with iron (III) oxide nanoparticles as lithium-ion battery anodes. Mater. Sci. Eng. B 241, 100-104. doi: 10.1016/j. mseb.2019.02.013

Mainka, H., Hilfert, L., Busse, S., Edelmann, F., Haak, E., and Herrmann, A. S. (2015a). Characterization of the major reactions during conversion of lignin to carbon fiber. J. Mater. Res. Technol. 4, 377-391. doi: 10.1016/j.jmrt.2015.04.005

Mainka, H., Täger, O., Körner, E., Hilfert, L., Busse, S., Edelmann, F. T., et al. (2015b). Lignin - an alternative precursor for sustainable and cost-effective automotive carbon fiber. J. Mater. Res. Techno. 4, 283-296. doi: 10.1016/j.jmrt. 2015.03.004

Meng, F., Song, M., Wei, Y., and Wang, Y. (2019). The contribution of oxygencontaining functional groups to the gas-phase adsorption of volatile organic compounds with different polarities onto lignin-derived activated carbon fibers. Environ. Sci. Pollut. Res. 26, 7195-7204. doi: 10.1007/s11356-019-04190-6

Mohanty, A. K., Vivekanandhan, S., Pin, J.-M., and Misra, M. (2018). Composites from renewable and sustainable resources: challenges and innovations. Science 362, 536-542. doi: 10.1126/science.aat 9072

Norberg, I., Nordström, Y., Drougge, R., Gellerstedt, G., and Sjöholm, E. (2013). A new method for stabilizing softwood kraft lignin fibers for carbon fiber production. Appl. Polym. 128, 3824-3830. doi: 10.1002/app.38588

Oroumei, A., Fox, B., and Naebe, M. (2015). Thermal and rheological characteristics of biobased carbon fiber precursor derived from low molecular weight organosolv Lignin. ACS Sust. Chem. Eng. 3, 758-769. doi: 10.1021/ acssuschemeng.5b00097

Perera Jayawickramage, R. A., Balkus, K. J., and Ferraris, J. P. (2019). Binder free carbon nanofiber electrodes derived from polyacrylonitrile-lignin blends for high performance supercapacitors. Nanotechnology 30:355402. doi: 10.1088/ 1361-6528/ab2274

Persano, L., Camposeo, A., Tekmen, C., and Pisignano, D. (2013). Industrial upscaling of electrospinning and applications of polymer nanofibers: a review. Macromol. Mater. Eng. 298, 504-520. doi: 10.1002/mame.201200290

Poursorkhabi, V. (2016). Production and Evaluation of Carbonized Electrospun Fibers from Bioethanol Lignin. Ph.D. Thesis, University of Guelph, Guelph, ON.

Poursorkhabi, V., Misra, M., and Mohanty, A. K. (2013). Extraction of lignin from a coproduct of the cellulosic ethanol industry and its thermal characterization. BioResources 8, 5083-5101.

Poursorkhabi, V., Mohanty, A. K., and Misra, M. (2015). Electrospinning of aqueous lignin/poly(ethylene oxide) complexes. J. Appl. Polym. Sci. 132:41260. doi: 10.1002/app.41260

Poursorkhabi, V., Mohanty, A. K., and Misra, M. (2016). Statistical analysis of the effects of carbonization parameters on the structure of carbonized electrospun organosolv lignin fibers. J. Appl. Polym. Sci. 133, 44005-44022. doi: 10.1002/ app. 44005

Prabu, G. T. V., and Dhurai, B. (2020). A novel profiled multi-pin electrospinning system for nanofiber production and encapsulation of nanoparticles into nanofibers. Sci. Rep. 10:4302. doi: 10.1038/s41598-020-60752-6

Ramakrishna, S., Fujihara, K., Teo, W. E., Lim, T. C., and Ma, Z. (2005). An Introduction to Electrospinning and Nanofibers. Singapore: World Scientific Publishing Co. Pte. Ltd.

Reneker, D. H., and Yarin, A. L. (2008). Electrospinning jets and polymer nanofibers. Polymer 49, 2387-2425. doi: 10.1016/j.polymer.2008.02.002

Reneker, D. H., Yarin, A. L., Fong, H., and Koombhongse, S. (2000). Bending instability of electrically charged liquid jets of polymer solutions in electrospinning. J. Appl. Phys. 87, 4531-4547. doi: 10.1063/1.373532

Rodríguez-Mirasol, J., Cordero, T., and Rodríguez, J. J. (1996). High-temperature carbons from kraft lignin. Carbon 34, 43-52. doi: 10.1016/0008-6223(95) 00133-6

Roman, J., Neri, W., Derré, A., and Poulin, P. (2019). Electrospun lignin-based twisted carbon nanofibers for potential microelectrodes applications. Carbon 145, 556-564. doi: 10.1016/j.carbon.2019.01.036

Ruiz-Rosas, R., Bedia, J., Lallave, M., Barrero, A., Loscertales, I. G., RodríguezMirasol, J., et al. (2010a). "Preparation and characterization of co-electrospun lignin/alumina microfibers and tubes," in Carbon, International Carbon Conference, Clemson, CA: American Carbon Society.

Ruiz-Rosas, R., Bedia, J., Lallave, M., Loscertales, I. G., Barrero, A., RodrßguezMirasol, J., et al. (2010b). The production of submicron diameter carbon fibers by the electrospinning of lignin. Carbon 48, 696-705. doi: 10.1016/j.carbon. 2009.10.014

Saito, T., Brown, R. H., Hunt, M. A., Pickel, D. L., Pickel, J. M., Messman, J. M., et al. (2012). Turning renewable resources into value-added polymer: development of lignin-based thermoplastic. Green Chem. 14, 3295-3303. doi: 10.1039/C2GC35933B

Salas, C., Ago, M., Lucia, L. A., and Rojas, O. J. (2014). Synthesis of soy proteinlignin nanofibers by solution electrospinning. React. Funct. Polym. 85, 221-227. doi: 10.1016/j.reactfunctpolym.2014.09.022

Saudi, A., Amini, S., Amirpour, N., Kazemi, M., Zargar Kharazi, A., Salehi, H., et al. (2019). Promoting neural cell proliferation and differentiation by incorporating lignin into electrospun poly(vinyl alcohol) and poly(glycerol sebacate) fibers. Mater. Sci. Eng. C 104:110005. doi: 10.1016/j.msec.2019.110005

Sauer, M. (2019). “Composites Market Report 2019”, in Carbon Composites. Frankfurt: AVK.

Schlee, P., Herou, S., Jervis, R., Shearing, P. R., Brett, D. J. L., Baker, D., et al. (2019a). Free-standing supercapacitors from Kraft lignin nanofibers with remarkable volumetric energy density. Chem. Sci. 10, 2980-2988. doi: 10.1039/ C8SC04936J

Schlee, P., Hosseinaei, O., Baker, D., Landmér, A., Tomani, P., Mostazo-López, M. J., et al. (2019b). From waste to wealth: from kraft lignin to freestanding supercapacitors. Carbon 145, 470-480. doi: 10.1016/j.carbon.2019. 01.035

Schreiber, M., Vivekanandhan, S., Cooke, P., Mohanty, A., and Misra, M. (2014). Electrospun green fibres from lignin and chitosan: a novel polycomplexation process for the production of lignin-based fibres. J. Mater. Sci. 49, 7949-7958. doi: 10.1007/s10853-014-8481-z

Schreiber, M., Vivekanandhan, S., Mohanty, A. K., and Misra, M. (2012). A Study on the electrospinning behaviour and nanofibre morphology of anionically charged lignin. Adv. Mater. Lett. 4, 476-480. doi: 10.5185/amlett.2012.icnano. 336

Schreiber, M., Vivekanandhan, S., Mohanty, A. K., and Misra, M. (2015). Iodine treatment of lignin-cellulose acetate electrospun fibres: enhancement of green fibre carbonization. ACS Sust. Chem. Eng. 3, 33-41. doi: 10.1021/sc500481k

Seo, D. K., Jeun, J. P., Kim, H. B., and Kang, P. H. (2011). Preparation and characterization of the carbon nanofiber mat produced from electrospun PAN/lignin precursors by electron beam irradiation. Rev. Adv. Mater. Sci. 28, 31-34.

Shi, X., Wang, X., Tang, B., Dai, Z., Chen, K., and Zhou, J. (2018). Impact of lignin extraction methods on microstructure and mechanical properties of lignin-based carbon fibers. J. Appl. Polym. Sci. 135:45580. doi: 10.1002/app. 45580

Shi, Z., Jin, G., Wang, J., and Zhang, J. (2017). Free-standing, welded mesoporous carbon nanofibers as anode for high-rate performance Li-ion batteries. J. Electroanal. Chem. 795, 26-31. doi: 10.1016/j.jelechem.2017. 03.047

Solomon, B. D., Barnes, J. R., and Halvorsen, K. E. (2007). Grain and cellulosic ethanol: history, economics, and energy policy. Biomass Bioenergy 31, 416-425. doi: 10.1016/j.biombioe.2007.01.023

Song, M., Yu, L., Song, B., Meng, F., and Tang, X. (2019). Alkali promoted the adsorption of toluene by adjusting the surface properties of lignin-derived carbon fibers. Environ. Sci. Pollut. Res. 26, 22284-22294. doi: 10.1007/s11356019-05456-9

Song, M., Zhang, W., Chen, Y., Luo, J., and Crittenden, J. C. (2017). The preparation and performance of lignin-based activated carbon fiber adsorbents for treating gaseous streams. Front. Chem. Sci. Eng. 11:328-337. doi: 10.1007/ s11705-017-1646-y

Suhas, A., Carrott, P. J. M., and Carrott, M. M. L. R. (2007). Lignin - from natural adsorbent to activated carbon: a review. Bioresour. Technol. 98, 2301-2312. doi: 10.1016/j.biortech.2006.08.008

Svinterikos, E., and Zuburtikudis, I. (2017). Tailor-made electrospun nanofibers of biowaste lignin/recycled Poly(Ethylene Terephthalate). J. Polym. he Environ. 25, 465-478. doi: 10.1007/s10924-0160806-3 
Svinterikos, E., Zuburtikudis, I., and Al-Marzouqi, M. (2019). The nanoscale dimension determines the carbonization outcome of electrospun lignin/ recycled-PET fibers. Chem. Eng. Sci. 202, 26-35. doi: 10.1016/j.ces.2019.03.013

Tagawa, T., and Miyata, T. (1997). Size effect on tensile strength of carbon fibers. Mater. Sci. Eng. A 238, 336-342. doi: 10.1016/S0921-5093(97)00454- 1

Tan, S., Huang, X., and $\mathrm{Wu}$, B. (2007). Some fascinating phenomena in electrospinning processes and applications of electrospun nanofibers. Polym. Int. 56, 1330-1339. doi: 10.1002/pi.2354

Tanaka, T., Nakayama, H., Sakaida, A., and Horikawa, N. (1999). Estimation of tensile strength distribution for carbon fiber with diameter variation along fiber. J. Soc. Mater. Sci. Jpn. 48, 90-97. doi: 10.2472/jsms.48.6Appendix_90

Teng, N.-Y., Dallmeyer, I., and Kadla, J. F. (2013). Incorporation of multiwalled carbon nanotubes into electrospun softwood kraft lignin-based fibers. J. Wood Chem. Technol. 33, 299-316. doi: 10.1080/02773813.2013.795807

Teo, W.-E., Inai, R., and Ramakrishna, S. (2011). Technological advances in electrospinning of nanofibers. Sci. Technol. Adv. Mater. 12, 1-19.

Thompson, C. J., Chase, G. G., Yarin, A. L., and Reneker, D. H. (2007). Effects of parameters on nanofiber diameter determined from electrospinning model. Polymer 48, 6913-6922. doi: 10.1016/j.polymer.2007.09.017

Vass, P., Szabó, E., Domokos, A., Hirsch, E., Galata, D., Farkas, B., et al. (2020). Scale-up of electrospinning technology: applications in the pharmaceutical industry. Wiley Interdiscip. Rev. 12:e1611. doi: 10.1002/wnan.1611

Wang, S.-X., Yang, L., Stubbs, L. P., Li, X., and He, C. (2013). Lignin-derived fused electrospun carbon fibrous mats as high performance anode materials for lithium ion batteries. ACS Appl. Mater. Interfaces 5, 12275-12282. doi: 10.1021/am4043867

Wang, W., Sun, Y., Liu, B., Wang, S., and Cao, M. (2015). Porous carbon nanofiber webs derived from bacterial cellulose as an anode for high performance lithium ion batteries. Carbon 91, 56-65. doi: 10.1016/j.carbon.2015.04.041

Wei, J., Geng, S., Kumar, M., Pitkänen, O., Hietala, M., and Oksman, K. (2019). Investigation of structure and chemical composition of carbon nanofibers developed from renewable precursor. Front. Mater. 6:334. doi: 10.3389/fmats. 2019.00334

Wei, L., Sun, R., Liu, C., Xiong, J., and Qin, X. (2019). Mass production of nanofibers from needleless electrospinning by a novel annular spinneret. Mater. Des. 179:107885. doi: 10.1016/j.matdes.2019.107885

Xing, W., Xue, J. S., and Dahn, J. R. (1996). Optimizing pyrolysis of sugar carbons for use as anode materials in lithium-ion batteries. J. Electrochem. Soc. 143, 3046-3052. doi: 10.1149/1.1837162

Xu, X., Zhou, J., Jiang, L., Lubineau, G., Chen, Y., Wu, X.-F., et al. (2013). Porous core-shell carbon fibers derived from lignin and cellulose nanofibrils. Mater. Lett. 109, 175-178. doi: 10.1016/j.matlet.2013.07.082

Xu, X., Zhou, J., Jiang, L., Lubineau, G., Payne, S. A., and Gutschmidt, D. (2014). Lignin-based carbon fibers: carbon nanotube decoration and superior thermal stability. Carbon 80, 91-102. doi: 10.1016/j.carbon.2014.08.042

Yang, H., Yan, R., Chen, H., Lee, D. H., and Zheng, C. (2007). Characteristics of hemicellulose, cellulose and lignin pyrolysis. Fuel 86, 1781-1788. doi: 10.1016/ j.fuel.2006.12.013

Yoo, S. H., Park, S., Park, Y., Lee, D., Joh, H.-I., Shin, I., et al. (2017). Facile method to fabricate carbon fibers from textile-grade polyacrylonitrile fibers based on electron-beam irradiation and its effect on the subsequent thermal stabilization process. Carbon 118, 106-113. doi: 10.1016/j.carbon.2017.03.039

Youe, W.-J., Lee, S.-M., Lee, S.-S., Lee, S.-H., and Kim, Y. S. (2015). Characterization of carbon nanofiber mats produced from electrospun ligning-polyacrylonitrile copolymer. Int. J. Biol. Macromol. 82, 497-504. doi: 10.1016/ j.ijbiomac.2015.10.022

Yu, B., Gele, A., and Wang, L. (2018). Iron oxide/lignin-based hollow carbon nanofibers nanocomposite as an application electrode materials for supercapacitors. Int. J. Biol. Macromol. 118, 478-484. doi: 10.1016/j.ijbiomac. 2018.06.088

Yun, S. I., Kim, S. H., Kim, D. W., Kim, Y. A., and Kim, B.-H. (2019). Facile preparation and capacitive properties of low-cost carbon nanofibers with $\mathrm{ZnO}$ derived from lignin and pitch as supercapacitor electrodes. Carbon 149, 637645. doi: 10.1016/j.carbon.2019.04.105

Zeng, Y., Zhao, S., Yang, S., and Ding, S.-Y. (2014). Lignin plays a negative role in the biochemical process for producing lignocellulosic biofuels. Curr. Opin. Biotechnol. 27, 38-45. doi: 10.1016/j.copbio.2013.09.008

Zhang, B., Kang, F., Tarascon, J.-M., and Kim, J.-K. (2016). Recent advances in electrospun carbon nanofibers and their application in electrochemical energy storage. Prog. Mater. Sci. 76, 319-380. doi: 10.1016/j.pmatsci.2015.08.002

Zhang, F., Wang, K.-X., Li, G.-D., and Chen, J.-S. (2009). Hierarchical porous carbon derived from rice straw for lithium ion batteries with high-rate performance. Electrochem. Commun. 11, 130-133. doi: 10.1016/j.elecom.2008. 10.041

Zhang, M., and Ogale, A. A. (2014). Carbon fibers from dry-spinning of acetylated softwood kraft lignin. Carbon 69, 626-629. doi: 10.1016/j.carbon.2013.12.015

Zhang, W., Yang, P., Li, X., Zhu, Z., Chen, M., and Zhou, X. (2019). Electrospun lignin-based composite nanofiber membrane as high-performance absorbent for water purification. Int. J. Biol. Macromol. 141, 747-755. doi: 10.1016/j. ijbiomac.2019.08.221

Zhao, L., and Wang, D. (2020). Combined effects of a biobutanol/ethanolgasoline (E10) blend and exhaust gas recirculation on performance and pollutant emissions. ACS Omega 5, 3250-3257. doi: 10.1021/acsomega.9b 03303

Zhao, Y., Liu, Y., Tong, C., Ru, J., Geng, B., Ma, Z., et al. (2018). Flexible ligninderived electrospun carbon nanofiber mats as a highly efficient and binder-free counter electrode for dye-sensitized solar cells. J. Mater. Sci. 53, 7637-7647. doi: 10.1007/s10853-018-2059-0

Conflict of Interest: The authors declare that this review article has been designed and written in collaboration with the industry partner HK, The Woodbridge Group. The Woodbridge Group has no financial interests in this article.

Copyright (c) 2020 Poursorkhabi, Abdelwahab, Misra, Khalil, Gharabaghi and Mohanty. This is an open-access article distributed under the terms of the Creative Commons Attribution License (CC BY). The use, distribution or reproduction in other forums is permitted, provided the original author(s) and the copyright owner(s) are credited and that the original publication in this journal is cited, in accordance with accepted academic practice. No use, distribution or reproduction is permitted which does not comply with these terms. 